WHOI-89-45

IMET TR-89-02

\title{
Improved Meteorological Measurements from Buoys and Ships (IMET): Preliminary Analysis of Solar Radiation and Motion Data from IMET Test Buoy.
}

\author{
by
}

Gennaro H. Crescenti, Robert A. Weller, David S. Hosom and Kenneth E. Prada

Woods Hole Oceanographic Institution

Woods Hole, Massachusetts 02543

October 1989

\section{Technical Report}

Funding was provided by the National Science Foundation under Grant No. OCE-87-09614

Reproduction in whole or in part is permitted for any purpose of the United States Government. This report should be cited as:

Woods Hole Oceanog. Inst. Tech. Rept., WHOI-89-45, IMET TR-89-02.

Approved for publication; distribution unlimited.

Approved for Distribution:

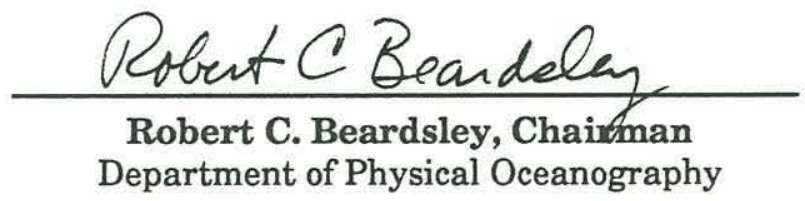




\section{Abstract}

Data are analyzed from a test buoy equipped with a motion sensor (Hippy) and two different pyranometers in order to understand and quantify motion induced errors in meteorological data. The Hippy measures pitch, roll, heave and acceleration of the buoy. Probability density functions and spectra of buoy motion and insolation are constructed and discussed. 


\section{Table of Contents}

1 Introduction and Motivation $\ldots \ldots \ldots \ldots \ldots$

2 Description of IMET Test Buoy and Sensors $\ldots \ldots \ldots \ldots$

3 Data Acquisition System $\ldots \ldots \ldots \ldots \ldots \ldots$

4 Weather and Wave Conditions $\ldots \ldots \ldots \ldots \ldots$

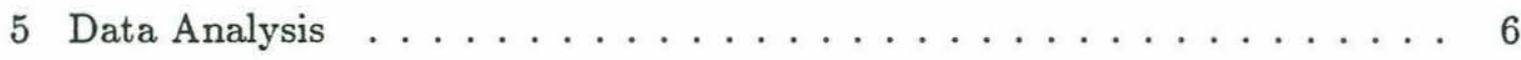

6 Summary and Conclusions $\ldots \ldots \ldots \ldots \ldots \ldots$

Acknowledgements . . . . . . . . . . . . . . . . . 10

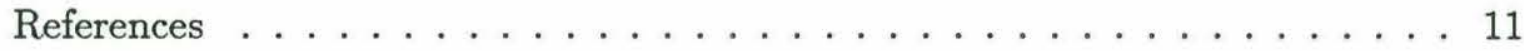

Tables . . . . . . . . . . . . . . . . . . . . . . 12

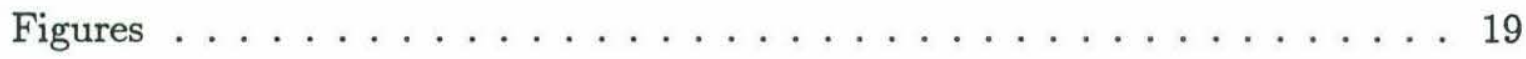




\section{Introduction and Motivation}

Some of the error in meteorological measurements made at sea is associated with the motion of those sensors and of the moving platform, ship or buoy on which they are mounted. In an attempt to better understand and quantify this error a buoy was fitted with a motion sensor and two different pyranometers.

Pyranometers measure the vertical flux of total direct solar and diffuse sky radiation integrated over a hemisphere. Because a pyranometer views a complete hemisphere, tilts in the sensor from horizontal will lead to erroneous values in measured irradiance. With a simple model, Katsaros and DeVault (1986) estimate errors in insolation values observed on buoys may be in excess of $20 \%$ due to rocking caused by wave action and preferential tilt of the buoy with respect to solar zenith and azimuth. The magnitudes of these errors are a function of tilt angle and tilt direction, latitude, time of day, time of year, and cloudiness.

This represents the first step in our attempt to quantify and reduce errors due to platform motion. To date, the buoy has been deployed only briefly. We plan next to collect longer time series of buoy motion under different conditions, to collect records of ship motion, and to investigate the effectiveness of gimbals in reduced motion induced error.

This report documents the installation of the Hippy on the buoy, the sensors, and the data acquisition system. It also presents data from the first deployment of the buoy. This work is done as part of the NSF-funded program to make Improved Meteorological Measurements from Buoys and Ships (IMET).

\section{Description of IMET Test Buoy and Sensors}

The IMET Test Buoy (Fig. 1) was a 3 meter discus buoy commonly used by the Woods Hole Oceanographic Institution (WHOI). The buoy was deployed at 
1911 UTC on 17 January 1989 and recovered the following day at 1445 UTC. The location was at the WHOI Buoy Farm off the coast of Rhode Island at $41^{\circ} 16^{\prime} \mathrm{N}$, $71^{\circ} 02^{\prime} \mathrm{W}$. Water depth was approximately 39 meters. The ship used for deployment and recovery was the $R / V$ Endeavor (EN-189).

The Datawell 120-B Hippy housing is cylindrical in shape measuring $60.6 \mathrm{~cm}$ in diameter and $80.8 \mathrm{~cm}$ in height and weighs $120 \mathrm{~kg}$. The Hippy was placed inside the well slightly off center of the buoy. The two pyranometers were placed on top of the tripod superstructure approximately $3 \mathrm{~m}$ high from the buoy deck which had an unobstructed view of the sky.

Power was provided by two 12 volt lead-acid batteries located in a water tight, vented box on the well cover. The LOPACS data logger was housed in an aluminum pressure case that was mounted vertically on the deck of the buoy. Later versions of the buoy configuration will use a smaller Hippy and have the data logger and batteries located inside the well. An ARGOS transmitter was mounted on the buoy tripod and configured for position only for this test. A VHF transmitter was also installed to permit line of sight data transmission from the buoy to the ship for real time monitoring during the test.

The signal outputs of the Hippy are pitch, roll, heave, and vertical acceleration. An accelerometer is mounted on a gravity stabilized platform with a natural time period of 120 seconds.

The pitch is defined as the angle between the roll axis of the ship and the horizontal plane. The pitch is positive when the rear of the ship is lifted. Similarly, the roll is the angle between the pitch axis of a ship and the horizontal plane. The roll is positive when the port side of the ship is lifted. The acceleration is positive during upward acceleration and likewise the heave is positive when displacement from rest is upwards. Table 1 lists specifications of the Hippy. 
Also included in the sensor package of this test buoy were two pyranometers. The first was an Eppley 8-48 Black and White Pyranometer. This sensor is a differential electroplated (copper-constantan) thermopile with the hot-junction receivers blackened and the cold-junction receivers whitened. The spectral response of the sensor is from 0.28 to 2.8 micrometers. The Schott WG7 glass dome that covers the thermopile is essentially transparent to this bandwith.

The second pyranometer was a Hollis MR-5 Silicon Cell Pyranometer. This silicon based sensor has an active band response of 0.4 to 1.2 micrometers but has been calibrated at the factory against thermal response pyranometers to effectively create a useful bandpass of 0.28 to 2.8 micrometers, essentially covering the entire range of the incoming solar spectrum. The MR-5 does not come with a protective glass dome like the Eppley 8-48. A summary of the factory specifications of both pyranometers is given in Table 2 .

Both pyranometers were amplified by a precision low noise amplifier. This was necessary in order to raise the signal levels within the proper dynamic range of the acquisition system.

These two pyranometers were chosen for their different time constants. The Eppley has a time constant of 3 to 4 seconds while the Hollis a time constant that is less than 1 second. The intention is to quantify the errors against the time response and better parameterize a correction factor.

\section{Data Acquisition System}

The system used to acquire and store data is a specially designed low-power IBM PC compatible computer with optical disk storage facilities. During the deployment the system acquired data for a 15 minute cycle each hour. Signals from the Hippy and pyranometers were digitized with a 16-bit analog-to-digital converter at a $4 \mathrm{~Hz}$ rate. During the active cycle, data was stored in a RAM disk file. The file 
was transferred to the optical disk for permanent storage at each cycle's end. Ten cycles were successfully completed during the deployment.

The buoy was recovered prematurely because of a failure in the computer system watchdog circuit. The circuit is responsible for awakening the system each hour. The system, an IMET prototype, was reset and again functioned properly. However, due to the uncertainty of another failure, the buoy was subsequently recovered.

\section{Weather and Wave Conditions}

The general overall weather picture during the test may be described as fair. Skies were partly to mostly sunny for the 17 and 18 January with some scattered stratocumulus clouds being more predominant early on 17 January. This can be seen in Fig. 2 from insolation values taken at Woods Hole. Wind speeds were moderate at 10 to $15 \mathrm{~m} \mathrm{~s}^{-1}$ from the southwest at the buoy farm (Figs. 3 and 4 ). Wind speeds dropped during the evening hours and veered to have a more westerly component. By the second day the winds were more northwesterly but were relatively light (less

than $5 \mathrm{~m} \mathrm{~s}^{-1}$ ). Sea swell was generally observed to come from the southwest from 1.0 to $3.0 \mathrm{~m}$ on the first day to less than a meter by 18 January.

The barometric pressure changed little during the cruise. The pressure had dropped slightly (Fig. 5) but the overall changes were relatively small. Air temperatures (Fig. 6) changed very little ranging from 3.5 to $6.5^{\circ} \mathrm{C}$. Sea surface temperatures also were relatively unremarkable (Fig. 7) ranging from 3 to $8^{\circ} \mathrm{C}$.

\section{Data Analysis}

The mean, variance and standard deviation were computed for the pitch, roll, heave, acceleration and insolation for all data files (Table 3). The minima and 
maxima were also computed for each variable. A summary of these statistics can be seen in Tables 4-13.

For much of the time that the buoy was deployed, the range of the pitch and roll was on the order of 10 degrees. However, the mean pitch and roll were not zero as there was a slight tilt in the buoy due to the off-set from center of the Hippy, computer, and lead-acid batteries. The mean acceleration while the buoy was deployed was approximately $0.4 \mathrm{~m} \mathrm{~s}^{-2}$. The mean insolation values were within several $\mathrm{W} \mathrm{m}^{-2}$ between the Eppley and Hollis pyranometers.

Of the ten data files recorded, three 15-minute files contain useful insolation data. These are 20 and 21 UTC on 17 January and 13 UTC on 18 January. The time series plots of these insolation data can be seen in Figs. 8, 9 and 10, respectively. Insolation values recorded at Woods Hole (approximately $40 \mathrm{~km}$ away) are over plotted on these figures.

It is immediately apparent that the MR-5 has a much noisier signal over the 8-48. This is because the MR-5 time response, for all practical purposes, is nearly instantaneous, whereas the time response of the 8-48 is on the order of several seconds. Hence, as the buoy moves back and forth across the sun, the MR- 5 can observe the large fluctuations in apparent incoming solar energy, while the 8-48 is much slower to respond. The objective is to relate the time response of these instruments to that of the buoy motion relative to the sun angle and determine, if possible, a quantitative correction.

Probability density functions (PDF) were computed for the pitch, roll, heave, and vertical acceleration. The pitch and roll (Figs. 11 and 12 respectively) show a large variance in the buoy early in the deployment (20 UTC) but was greatly reduced by the next day (13 UTC) when the sea state was much calmer. Winds were relatively strong when the buoy was first deployed and the sea state was moderately rough with swell of 1-2 m. However, by the next day the winds had decreased 
significantly and sea state was very near calm. The PDF's for buoy pitch and roll show significantly less rocking motion compared to that seen in the previous day.

The PDF's show heave (Fig. 13) up to $\pm 2.0 \mathrm{~m}$ at 20 UTC but was down to less than $\pm 1.0 \mathrm{~m}$ by the next day when sea state had calmed. The vertical acceleration (Fig. 14) also typifies the before and after scenarios.

Spectral analysis was performed on these variables. Spectra of the pitch is shown in Figs. 15 and 16 for 20 UTC and 13 UTC, respectively. The energy . containing frequencies occur between 0.2 and $0.5 \mathrm{~Hz}$, corresponding to wave periods of 2 to 5 seconds. Spectra of the roll are nearly identical to that of the pitch. The power drops for the spectra by 13 UTC on 18 January as the sea state calmed. The spectral peak had also shifted slightly towards the higher frequencies.

Heave spectra are shown in Fig. 17 and the acceleration spectra in Fig. 18 for 20 UTC on 17 January. A sharp peak exists for the heave at about $0.2 \mathrm{~Hz}$. Most of the energy containing frequencies for the acceleration lie between 0.15 and $0.5 \mathrm{~Hz}$. The spectral power for the lower frequencies is nearly nonexistent.

The spectra of the two pyranometers match up well from the lowest frequencies up to about $0.1 \mathrm{~Hz}$. From 0.1 to $1 \mathrm{~Hz}$ the spectral powers of the two sensors are very much different. Fig. 19 shows the spectra of the two pyranometers for 20 UTC on 17 January. The Eppley spectra continues to decay whereas the Hollis spectra mimics the pitch/roll spectra. This is also again true for 13 UTC on 18 January (Fig. 20).

This information tells us that the Eppley 8-48 pyranometer has a time constant on the order of 10 seconds rather than the quoted 3 to 4 seconds. The Hollis pyranometer, on the other hand, mimics the pitch motion very well. It may be possible to correct for this error spectrally, much like that exhibited by Dugan et al. (1989). 


\section{Summary and Conclusions}

The implications of this work go far beyond corrections for insolation data on buoys. Other sensors such as pyrgeometers, wind sensors, and rain gauges would also suffer the same ill affects of buoy motion. For instance, Dugan et al. (1989) correct wind data on a buoy spectrally using Hippy pitch, roll, and heave data.

There are several recommendations for improvements for future tests such as the one described here in this report. First, a compass included in the sensor package of the IMET test buoy would help determine the orientation of the buoy with respect to the sun position. This way, data obtained from the pyranometers from the buoy can be checked against the model by Katsaros and DeVault (1986). Second, a larger data set will be needed for such an exercise. When the IMET test buoy was deployed and for much of the deployment, skies were partially overcast with clouds. Clear sky conditions would be ideal to compare against the above mentioned model since it is based on clear sky conditions.

Two similar pyranometers should be tested with the Hippy. One pyranometer should be rigidly mounted to the superstructure of the buoy while the second pyranometer mounted on a gimbaled platform. This may also be done on a ship. With this type of arrangement, a systematic error analysis may be conducted and, hopefully, a parameterization scheme that may allow us to minimize the errors associated with platform induced motions. 


\section{Acknowledgements}

The authors wish to thank the Captain and crew of the R/V Endeavor and the WHOI Buoy Group for their assistance in deploying and recovering the discus buoy. The authors also wish to thank Barbara Graffron for reviewing this report and making helpful suggestions.

The work was funded by the National Science Foundation (Grant OCE-8709614) as a World Ocean Circulation Experiment (WOCE) long-lead time development activity. 


\section{References}

Dugan, J. P., S. L. Panichas, W. D. Morris, and K. C. Vierra, 1989. Performance evaluation of the MINIMET air-sea interactions buoy. Conference and Exposition on Marine Data Systems, Proceedings. New Orleans, Louisiana, April 26-28, pp. 69-75.

Katsaros, K. B., and J. E. DeVault, 1986. On irradiance measurement errors at sea due to tilt of pyranometers. Journal of Atmospheric and Oceanic Technology, 3, 740-745. 
Table 1: Hippy 120-B Specifications

\begin{tabular}{lcccc} 
Variable & Range & Accuracy & Zero Offset & Noise \\
\hline Pitch & -90 to $90 \mathrm{deg}$ & $<0.5 \%$ & $<0.5 \mathrm{deg}$ & $<0.05 \mathrm{deg}$ \\
Roll & -90 to $90 \mathrm{deg}$ & $<0.5 \%$ & $<0.5 \mathrm{deg}$ & $<0.05 \mathrm{deg}$ \\
Heave & -10 to $10 \mathrm{~m}$ & $<1.5 \%$ & $<0.05 \mathrm{~m}$ & $<0.03 \mathrm{~m}$ \\
Acceleration & -10 to $10 \mathrm{~m} / \mathrm{s}^{2}$ & $<1.5 \%$ & $<1.0 \mathrm{~m} / \mathrm{s}^{2}$ & - \\
\hline
\end{tabular}

Table 2: Pyranometer Specifications

\begin{tabular}{lcc} 
& $\begin{array}{c}\text { Eppley } \\
8-48\end{array}$ & $\begin{array}{c}\text { Hollis } \\
\text { MR-5 }\end{array}$ \\
\hline $\begin{array}{l}\text { Serial Number } \\
\text { Sensitivity }\left(u V /\left(\mathrm{W} / \mathrm{m}^{2}\right)\right)\end{array}$ & 10420 & $5-192$ \\
$\begin{array}{l}\text { Linearity with Temperature } \\
\left(-20 \text { to } 40^{\circ} \mathrm{C}\right)\end{array}$ & 11 & 72 \\
$\begin{array}{l}\text { Linearity with Intensity } \\
\quad\left(\text { Spectral range } 0-1400 \mathrm{~W} / \mathrm{m}^{2}\right)\end{array}$ & $1.5 \%$ & $1.5 \%$ \\
Cosine Response & $1.5 \%(0-80 \mathrm{deg})$ & $2 \%(0-70 \mathrm{deg})$ \\
$\begin{array}{l}\text { Time Response }(\mathrm{sec}) \\
\text { Calibration Coefficient } \\
\quad\left(\times 1 \mathrm{E}-6 \text { VDC } /\left(\mathrm{W} / \mathrm{m}^{2}\right)\right)\end{array}$ & $3-4$ & $5 \%(70-80 \mathrm{deg})$ \\
Gain & 10.45 & $<1$ \\
\hline
\end{tabular}


Table 3: Summary of Data Files

\begin{tabular}{cl}
$\begin{array}{c}\text { File Name } \\
\text { (YYMMDDHH) }\end{array}$ & Location of Buoy \\
\hline 89011718 & Ship Deck \\
89011719 & Partially Deployed \\
89011720 & Deployed \\
89011721 & Deployed \\
89011722 & Deployed \\
89011723 & Deployed \\
89011800 & Deployed \\
89011813 & Deployed \\
89011815 & Ship Deck \\
89011816 & Ship Deck \\
\hline where: & YY $=$ Year \\
MM $=$ Month \\
DD = Day \\
HH = Hour (UTC)
\end{tabular}

Table 4: Variable Statistics - 17 JAN $89-18$ UTC

\begin{tabular}{|c|c|c|c|c|c|}
\hline Variable & Minimum & Maximum & Mean & $\begin{array}{l}\text { Standard } \\
\text { Deviation }\end{array}$ & Variance \\
\hline Pitch deg) & 34.125 & 43.267 & 38.869 & 1.523 & 2.318 \\
\hline Roll (deg) & -37.243 & -29.446 & -33.368 & 1.249 & 1.561 \\
\hline Heave (m) & -10.000 & 1.122 & -1.317 & 3.037 & 9.224 \\
\hline Accel $\left(\mathrm{m} / \mathrm{s}^{2}\right)$ & -1.248 & 2.010 & 0.403 & 0.378 & 0.143 \\
\hline Eppley $\left(\mathrm{W} / \mathrm{m}^{2}\right)$ & 112.180 & 748.347 & 236.062 & 189.857 & 36045.860 \\
\hline Hollis $\left(\mathrm{W} / \mathrm{m}^{2}\right)$ & 67.004 & 869.695 & 235.999 & 232.434 & 54025.620 \\
\hline
\end{tabular}




\section{Table 5: Variable Statistics - 17 JAN 89 - 19 UTC}

\begin{tabular}{lrrrrr} 
Variable & & & & Standard \\
& Minimum & Maximum & Mean & Deviation & Variance \\
Pitch (deg) & & & & & \\
Roll (deg) & -6.742 & 19.050 & 4.887 & 3.574 & 12.773 \\
Heave (m) & -18.844 & 6.823 & -3.930 & 3.444 & 11.862 \\
Accel $\left(\mathrm{m} / \mathrm{s}^{2}\right)$ & -4.000 & 9.988 & -0.999 & 3.428 & 11.753 \\
Eppley $\left(\mathrm{W} / \mathrm{m}^{2}\right)$ & 285.648 & 417.540 & 348.884 & 3.268 & 1.607 \\
Hollis $\left(\mathrm{W} / \mathrm{m}^{2}\right)$ & 67.685 & 531.953 & 321.455 & 66.934 & 953.851 \\
\hline
\end{tabular}

Table 6: Variable Statistics - 17 JAN 89-20 UTC

\begin{tabular}{lrrrrr} 
Variable & & & & Standard & \\
& Minimum & Maximum & Mean & Deviation & Variance \\
Pitch (deg) & & & & & \\
Roll $(\mathrm{deg})$ & -3.991 & 14.454 & 3.059 & 1.901 & 3.613 \\
Heave (m) & -9.718 & 6.488 & -0.991 & 2.035 & 4.142 \\
Accel $\left(\mathrm{m} / \mathrm{s}^{2}\right)$ & -10.000 & 9.922 & -0.921 & 3.445 & 11.867 \\
Eppley $\left(\mathrm{W} / \mathrm{m}^{2}\right)$ & -2.680 & 6.052 & 0.402 & 1.217 & 1.480 \\
Hollis $\left(\mathrm{W} / \mathrm{m}^{2}\right)$ & 121.499 & 154.114 & 136.293 & 6.675 & 44.558 \\
\hline
\end{tabular}


Table 7: Variable Statistics -17 JAN $89-21$ UTC

\begin{tabular}{lrrrrr} 
& & & & Standard \\
Variable & Minimum & Maximum & Mean & Deviation & Variance \\
\hline Pitch (deg) & & & & & \\
Roll $(\mathrm{deg})$ & -4.508 & 16.690 & 3.387 & 2.047 & 4.188 \\
Heave $(\mathrm{m})$ & -10.002 & 5.428 & -2.051 & 2.241 & 5.023 \\
Accel $\left(\mathrm{m} / \mathrm{s}^{2}\right)$ & -3.158 & 9.992 & -0.925 & 3.436 & 11.805 \\
Eppley $\left(\mathrm{W} / \mathrm{m}^{2}\right)$ & 35.124 & 63.079 & 0.400 & 1.184 & 1.402 \\
Hollis $\left(\mathrm{W} / \mathrm{m}^{2}\right)$ & 35.033 & 78.228 & 45.175 & 4.878 & 23.798 \\
\hline
\end{tabular}

Table 8: Variable Statistics - 17 JAN $89-22$ UTC

$\begin{array}{lrrrrr}\text { Variable } & & & & \text { Standard } & \\ & \text { Minimum } & \text { Maximum } & \text { Mean } & \text { Deviation } & \text { Variance } \\ \text { Pitch (deg) } & & & & & \\ \text { Roll (deg) } & -4.566 & 13.238 & 2.620 & 2.115 & 4.474 \\ \text { Heave (m) } & -15.581 & 7.181 & -1.859 & 2.199 & 4.836 \\ \text { Accel }\left(\mathrm{m} / \mathrm{s}^{2}\right) & -3.000 & 9.618 & -0.967 & 3.458 & 11.961 \\ \text { Eppley }\left(\mathrm{W} / \mathrm{m}^{2}\right) & 7.168 & 5.584 & 0.402 & 1.233 & 1.521 \\ \text { Hollis }\left(\mathrm{W} / \mathrm{m}^{2}\right) & 4.081 & 15.279 & 13.371 & 0.829 & 0.687 \\ & & & & & \end{array}$


Table 9: Variable Statistics - 17 JAN $89-23$ UTC

\begin{tabular}{lrrrrr} 
Variable & & & & Standard & \\
& Minimum & Maximum & Mean & Deviation & Variance \\
Pitch (deg) & & & & & \\
Roll (deg) & -7.389 & 13.332 & 2.397 & 2.029 & 4.117 \\
Heave (m) & -15.855 & 7.077 & -1.661 & 2.324 & 5.401 \\
Accel $\left(\mathrm{m} / \mathrm{s}^{2}\right)$ & -10.000 & 9.864 & -0.953 & 3.417 & 11.677 \\
Eppley $\left(\mathrm{W} / \mathrm{m}^{2}\right)$ & -3.904 & 6.440 & 0.407 & 1.252 & 1.568 \\
Hollis $\left(\mathrm{W} / \mathrm{m}^{2}\right)$ & 6.810 & 17.920 & 13.107 & 0.863 & 0.744 \\
\hline
\end{tabular}

Table 10: Variable Statistics - 18 JAN 89 - 00 UTC

\begin{tabular}{lrrrrr} 
& & & & Standard & \\
Variable & Minimum & Maximum & Mean & Deviation & Variance \\
\hline Pitch (deg) & & & & & \\
Roll $(\mathrm{deg})$ & -3.899 & 15.129 & 3.009 & 2.232 & 4.982 \\
Heave $(\mathrm{m})$ & -20.573 & 7.008 & -2.325 & 2.523 & 6.365 \\
Accel $\left(\mathrm{m} / \mathrm{s}^{2}\right)$ & -10.000 & 9.692 & -0.877 & 3.430 & 11.762 \\
Eppley $\left(\mathrm{W} / \mathrm{m}^{2}\right)$ & -3.126 & 5.212 & 0.386 & 1.224 & 1.498 \\
Hollis $\left(\mathrm{W} / \mathrm{m}^{2}\right)$ & 6.810 & 17.562 & 13.249 & 0.842 & 0.709 \\
\hline
\end{tabular}


Table 11: Variable Statistics - 18 JAN $89-13$ UTC

\begin{tabular}{lrrrrr} 
Variable & & & & Standard \\
& Minimum & Maximum & Mean & Deviation & Variance \\
Pitch (deg) & & & & & \\
Roll (deg) & -0.195 & 8.882 & 3.118 & 1.095 & 1.198 \\
Heave (deg) & -4.003 & 4.922 & -0.000 & 1.029 & 1.059 \\
Accel $\left(\mathrm{m} / \mathrm{s}^{2}\right)$ & -10.000 & 10.000 & -0.383 & 3.503 & 12.270 \\
Eppley $\left(\mathrm{W} / \mathrm{m}^{2}\right)$ & 293.174 & 2.624 & 0.349 & 0.505 & 0.255 \\
Hollis $\left(\mathrm{W} / \mathrm{m}^{2}\right)$ & 234.345 & 382.631 & 324.844 & 15.802 & 249.702 \\
\hline
\end{tabular}

Table 12: Variable Statistics - 18 JAN $89-15$ UTC

\begin{tabular}{lrrrrr} 
Variable & & & & Standard \\
& Minimum & Maximum & Mean & Deviation & Variance \\
\hline Pitch (deg) & & & & & \\
Roll (deg) & 38.682 & 48.677 & 43.524 & 1.489 & 2.218 \\
Heave (m) & -31.534 & -23.753 & -28.143 & 1.276 & 1.627 \\
Accel $\left(\mathrm{m} / \mathrm{s}^{2}\right)$ & -0.000 & 9.922 & -0.931 & 3.332 & 11.102 \\
Eppley $\left(\mathrm{W} / \mathrm{m}^{2}\right)$ & 93.543 & 1.518 & 0.343 & 0.316 & 0.100 \\
Hollis $\left(\mathrm{W} / \mathrm{m}^{2}\right)$ & 74.147 & 1149.277 & 289.404 & 271.152 & 73523.530 \\
\hline
\end{tabular}




\section{Table 13: Variable Statistics - 18 JAN 89 - 16 UTC}

\begin{tabular}{lrrrrr} 
Variable & & & & Standard \\
& Minimum & Maximum & Mean & Deviation & Variance \\
\hline Pitch (deg) & & & & & \\
Roll (deg) & 40.421 & 48.108 & 44.278 & 1.372 & 1.881 \\
Heave (m) & -30.637 & -23.254 & -26.899 & 1.205 & 1.452 \\
Accel $\left(\mathrm{m} / \mathrm{s}^{2}\right)$ & -10.000 & 9.924 & -0.925 & 3.301 & 10.895 \\
Eppley $\left(\mathrm{W} / \mathrm{m}^{2}\right)$ & 0.000 & 0.704 & 0.342 & 0.100 & 0.010 \\
Hollis $\left(\mathrm{W} / \mathrm{m}^{2}\right)$ & 310.736 & 469.509 & 411.879 & 31.927 & 1019.343 \\
\hline
\end{tabular}




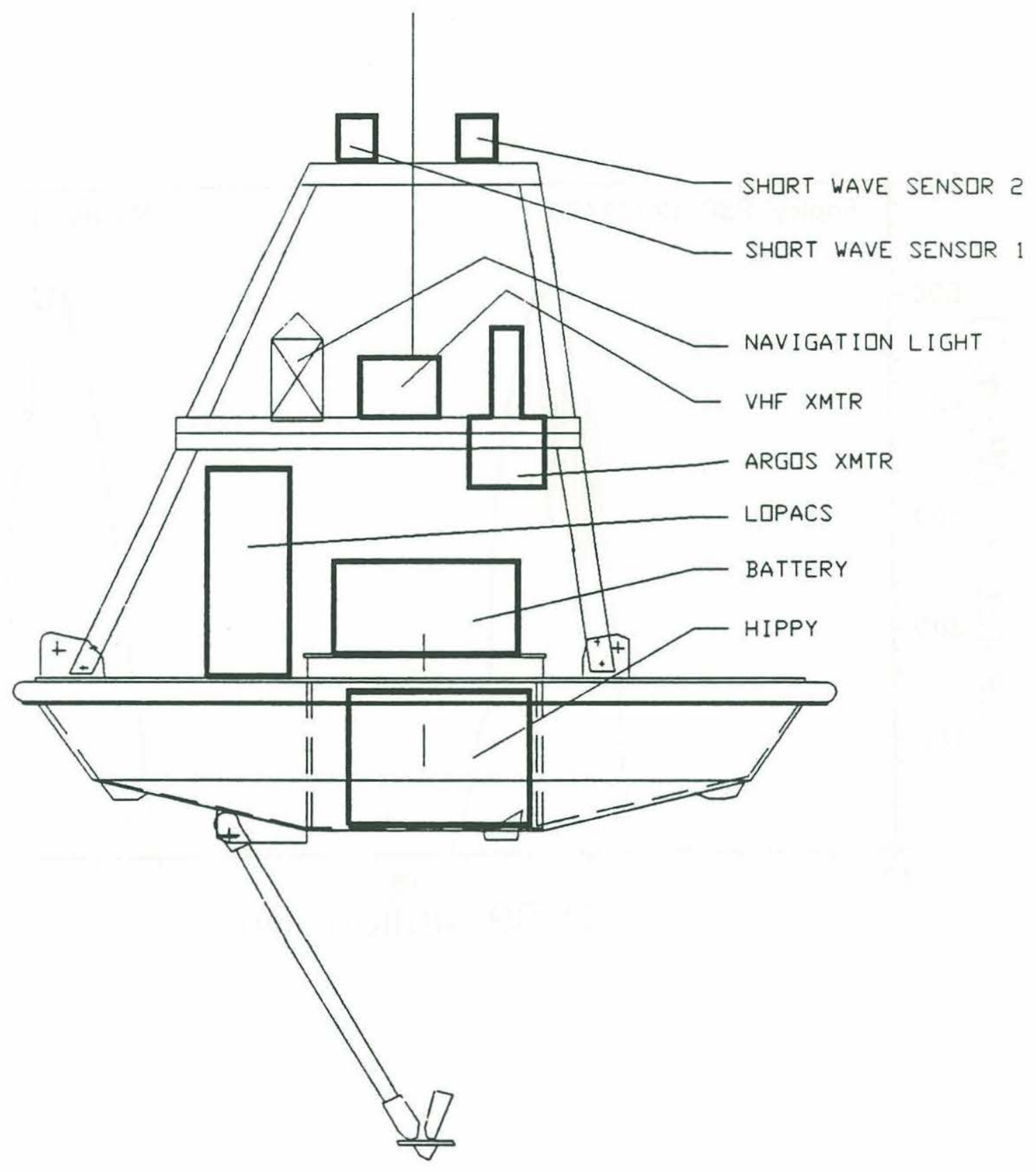

Figure 1: Line drawing of IMET Test Buoy. 


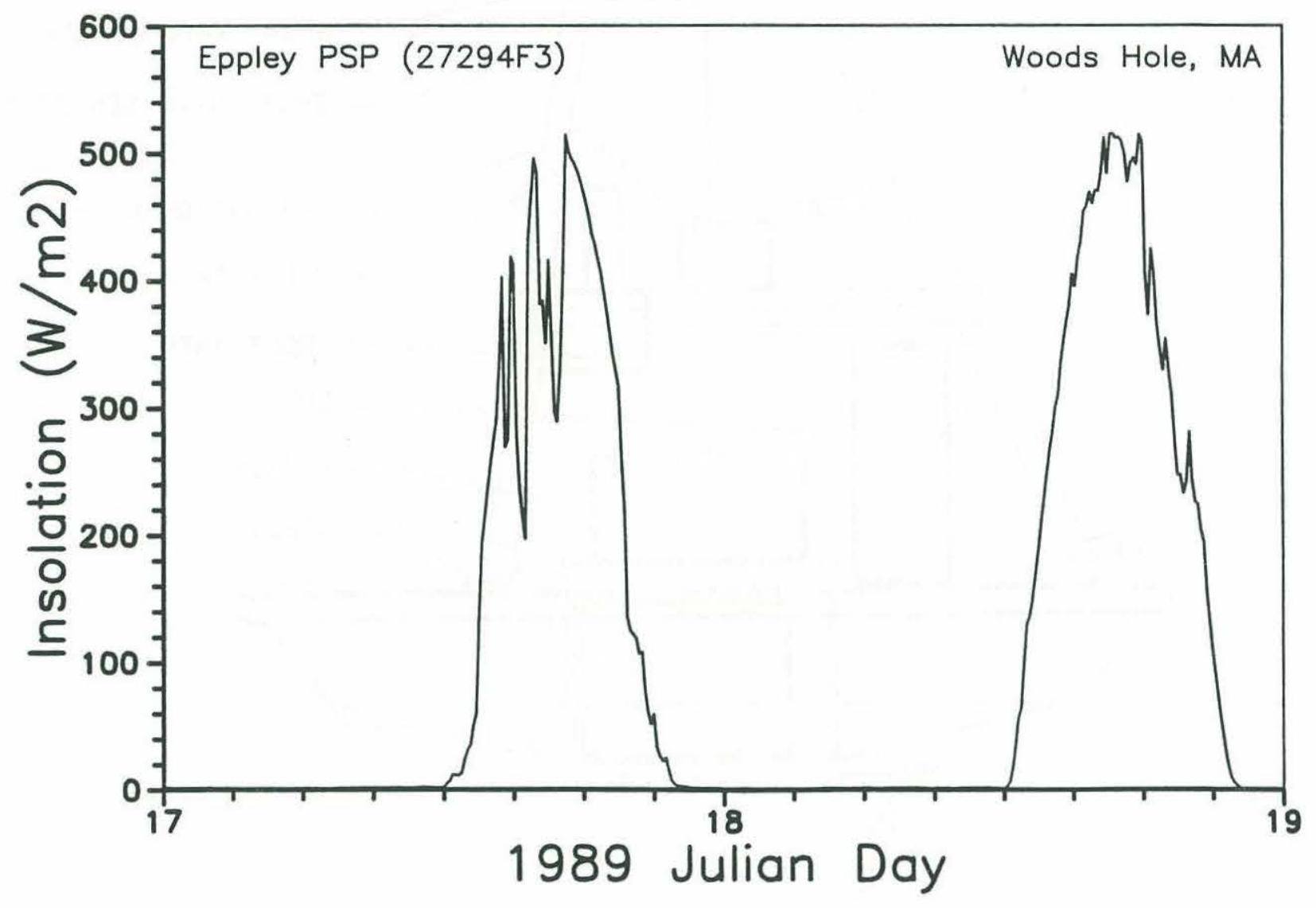

Figure 2: Insolation values for 17 and 18 January observed at Woods Hole, Massachusetts, by an Eppley Precision Spectral Pyranometer. WHOI Buoy Farm is approximately $40 \mathrm{~km}$ away. 


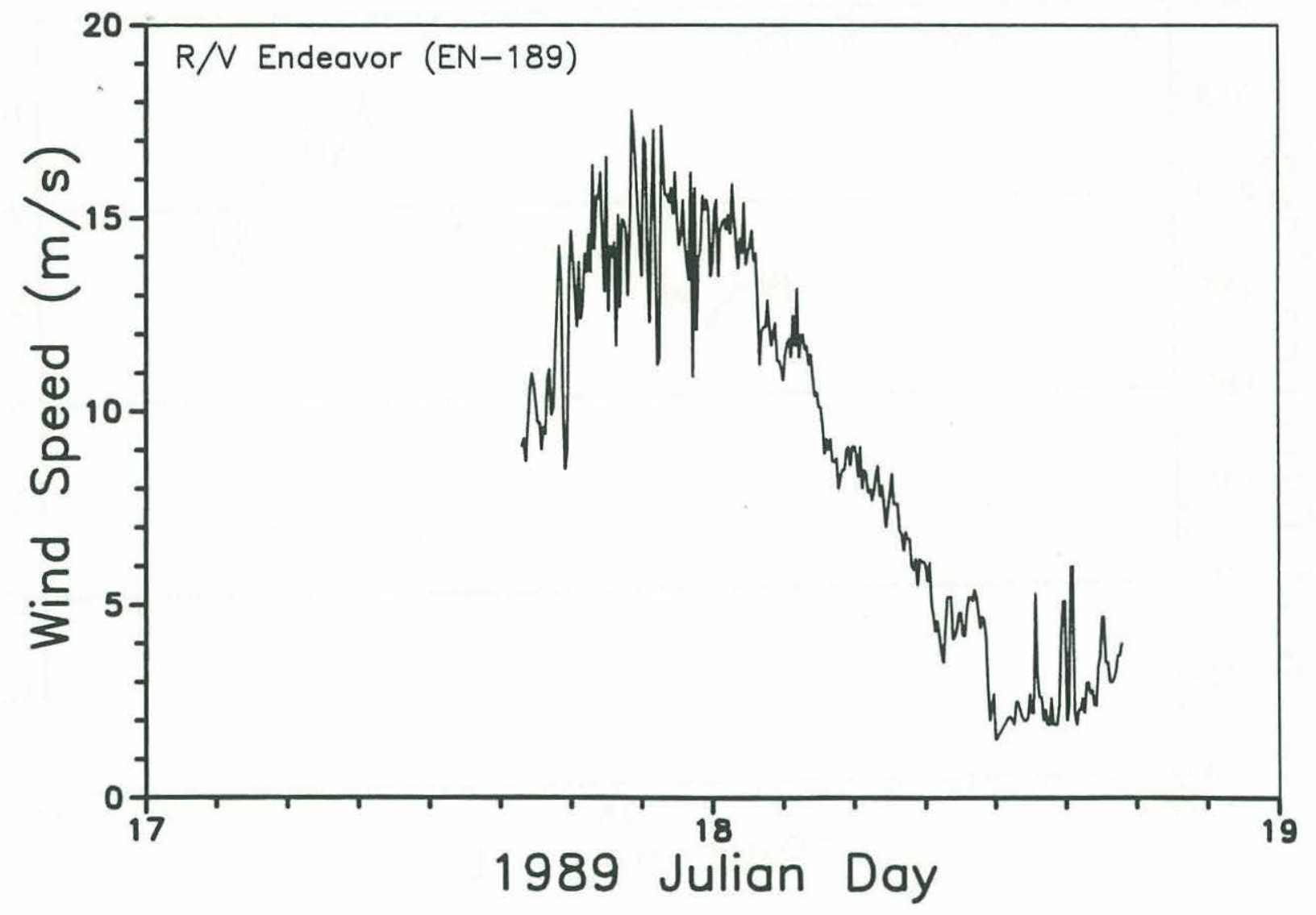

Figure 3: Wind speeds recorded by the $R / V$ Endeavor during cruise EN-189. Sampling rate is 5 minutes. 


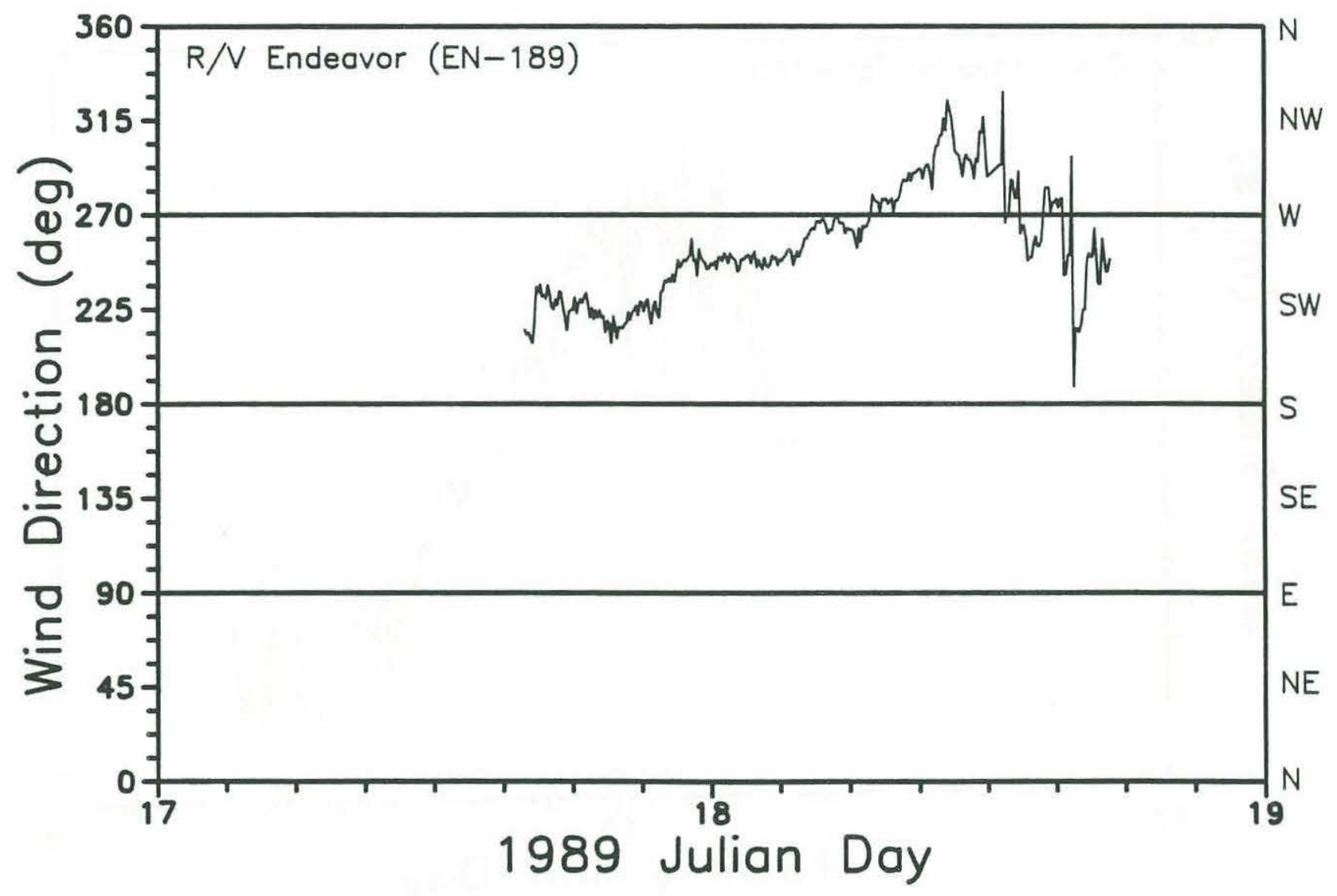

Figure 4: Wind direction recorded by the $R / V$ Endeavor during cruise EN-189. Sampling rate is 5 minutes. 


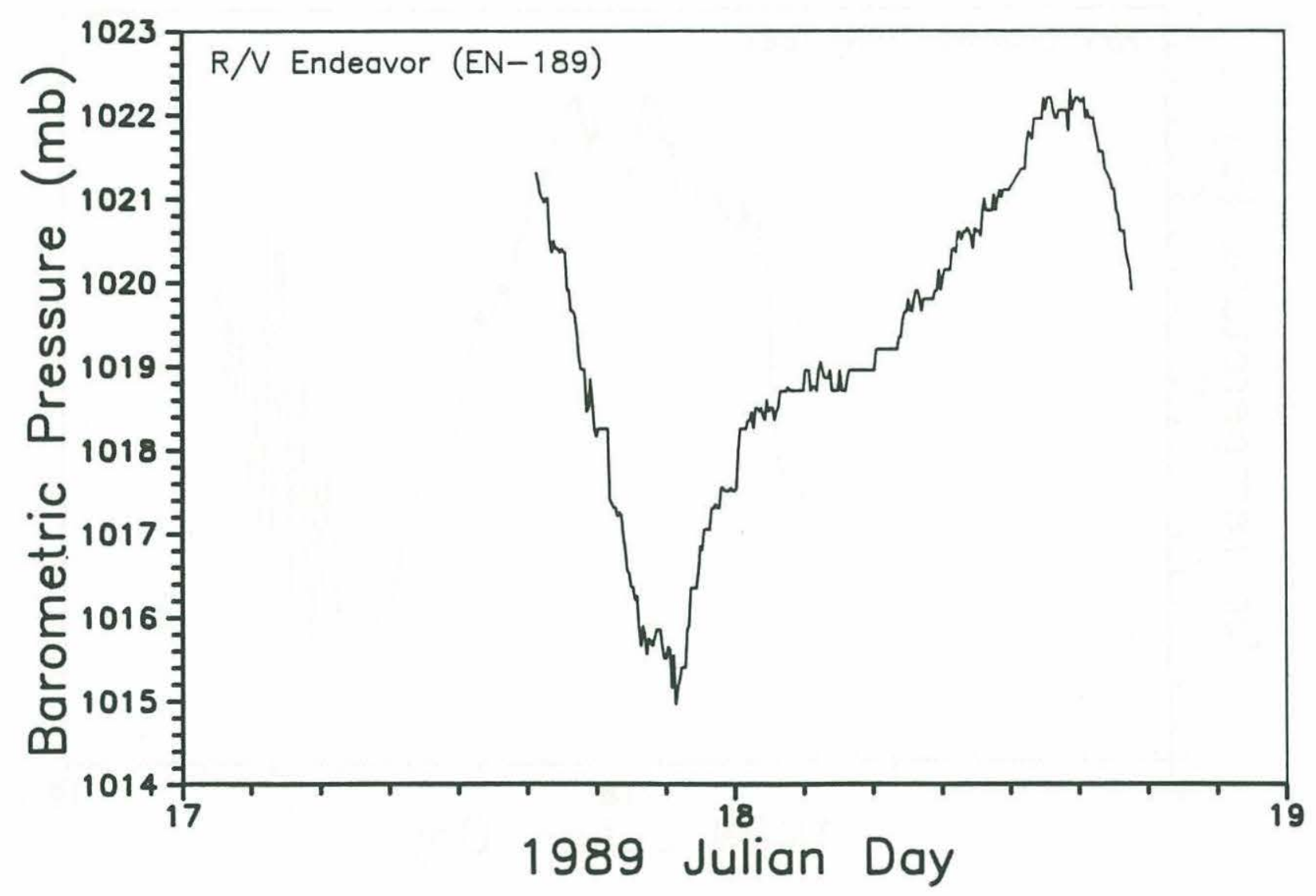

Figure 5: Barometric pressure recorded by the $R / V$ Endeavor during cruise EN-189. Sampling rate is 5 minutes. 


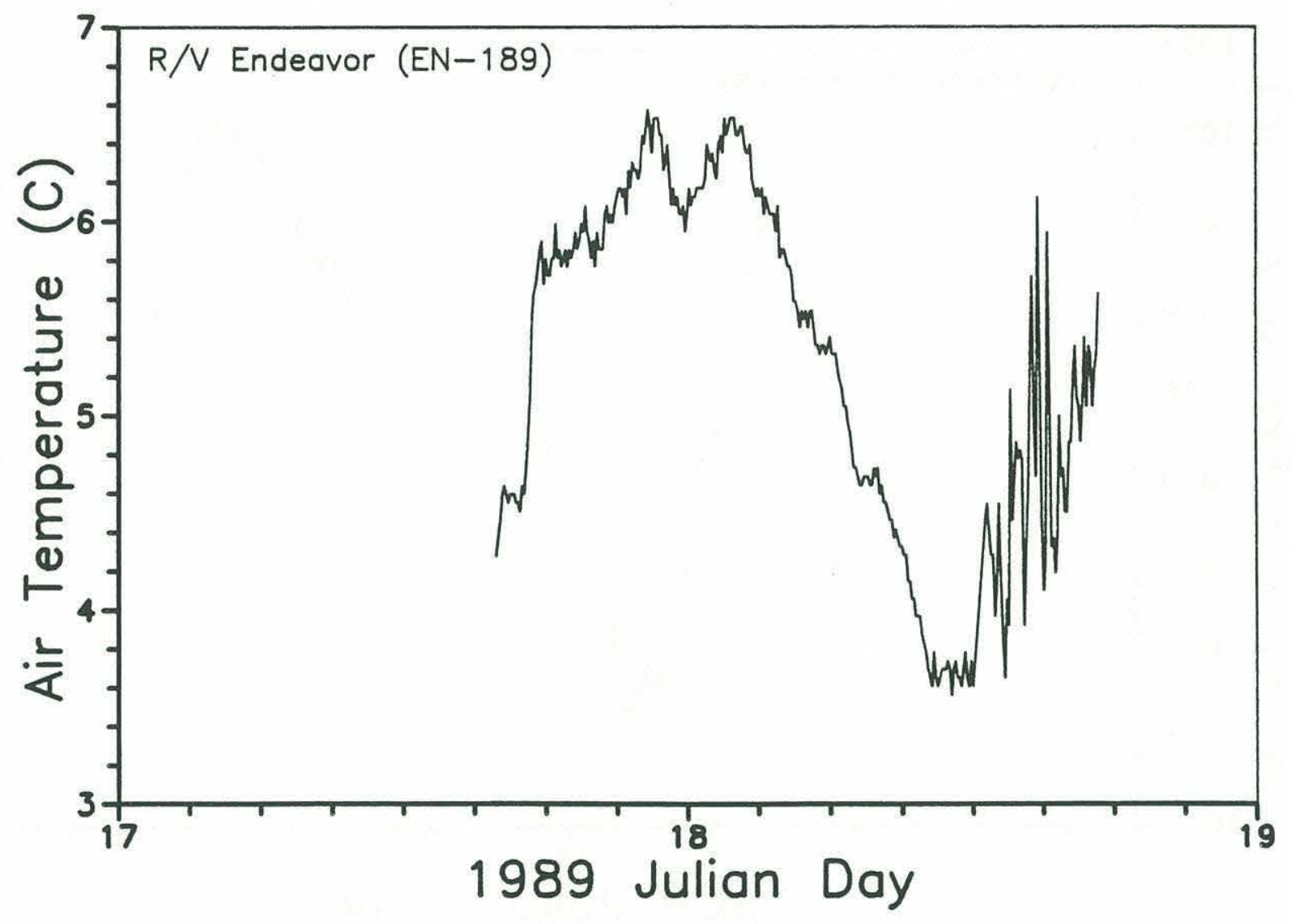

Figure 6: Air temperature recorded by the $R / V$ Endeavor during cruise EN-189. Sampling rate is 5 minutes. 


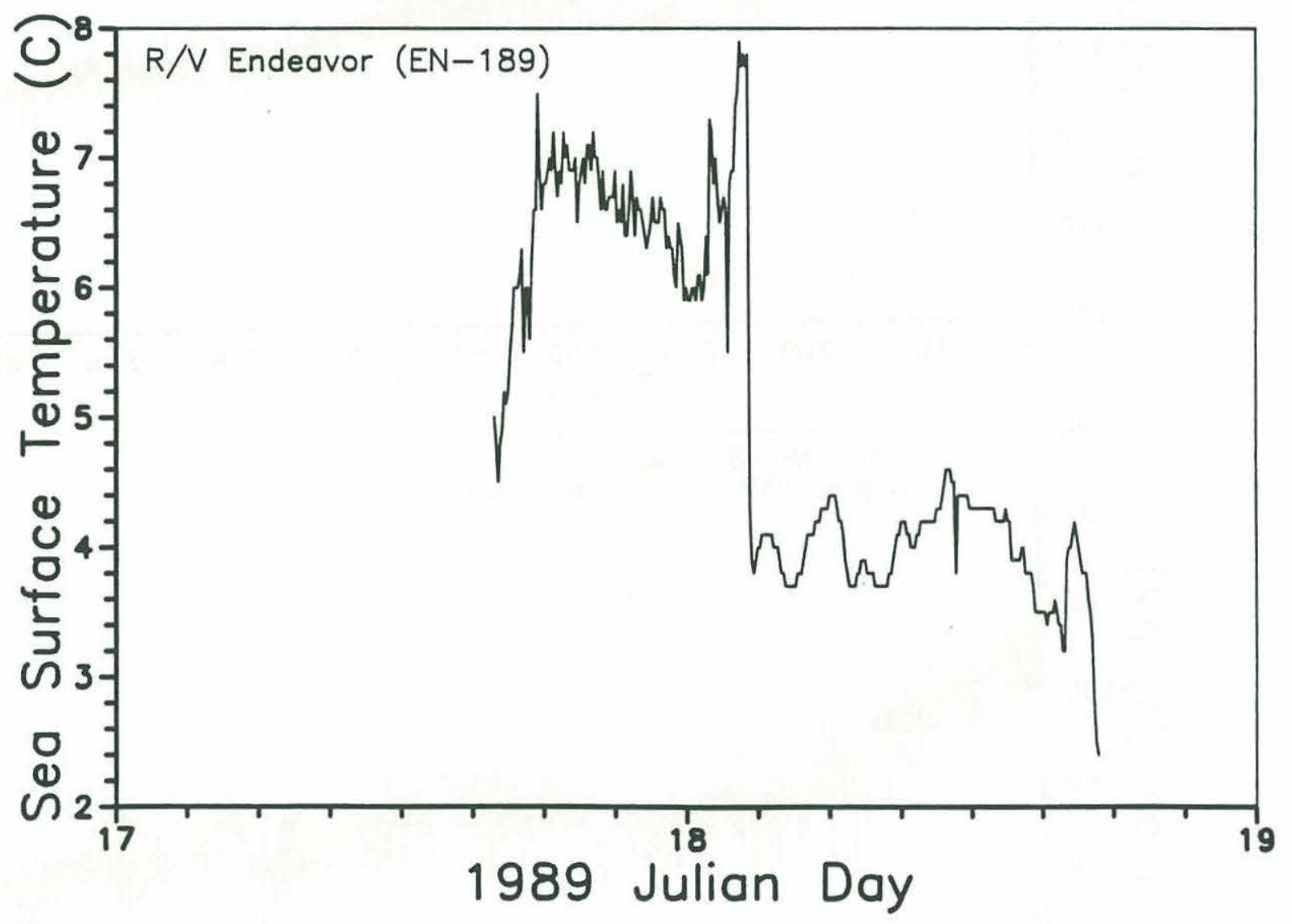

Figure 7: Sea surface temperature recorded by the $R / V$ Endeavor during cruise EN-189. Sampling rate is 5 minutes. 

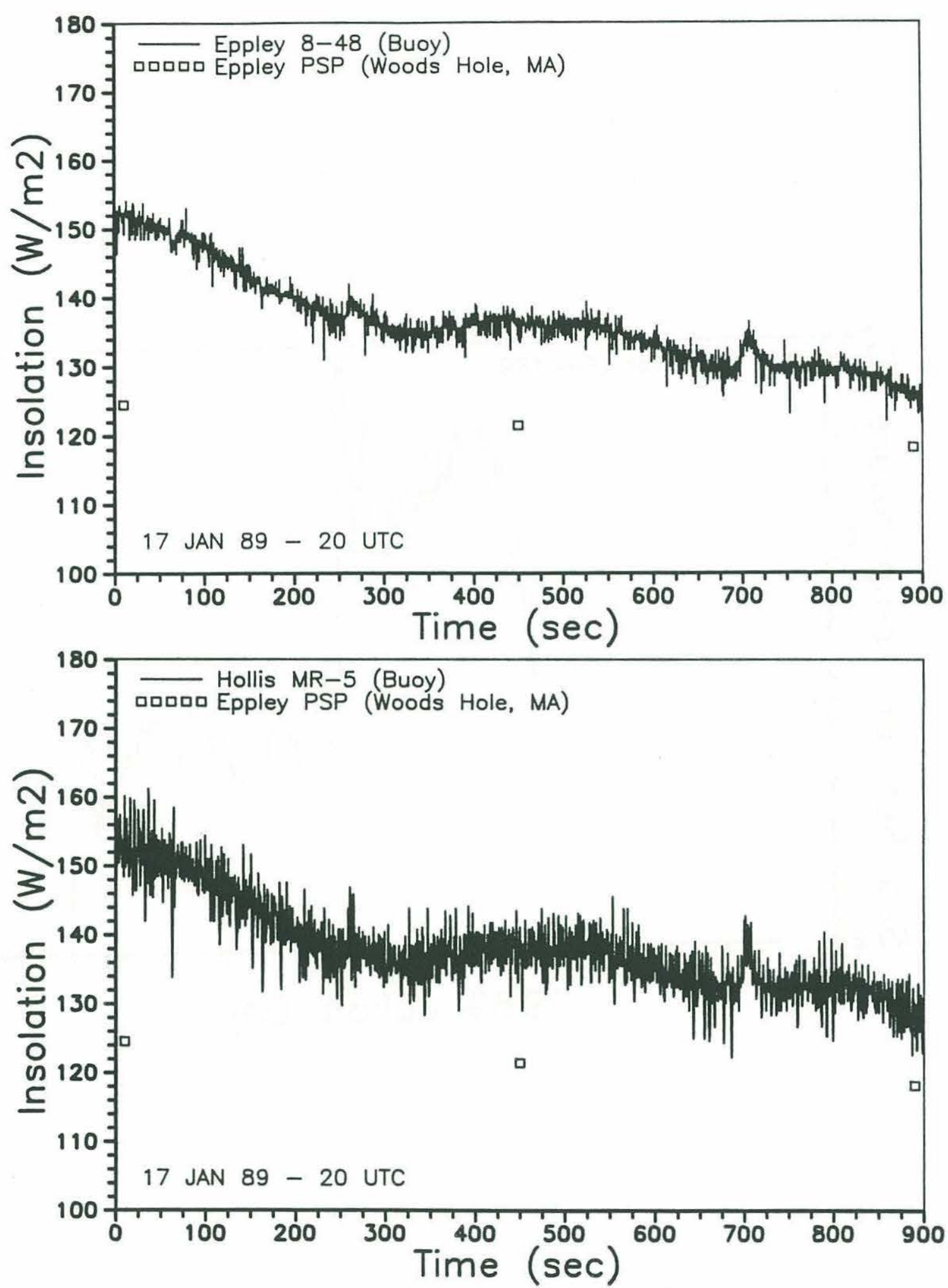

Figure 8: Insolation values recorded on test buoy on 17 January 1989 at 20 UTC.

Sampling rate for insolation on buoy is $4 \mathrm{~Hz}$. Insolation values from Woods Hole are 7.5 minute averages. 

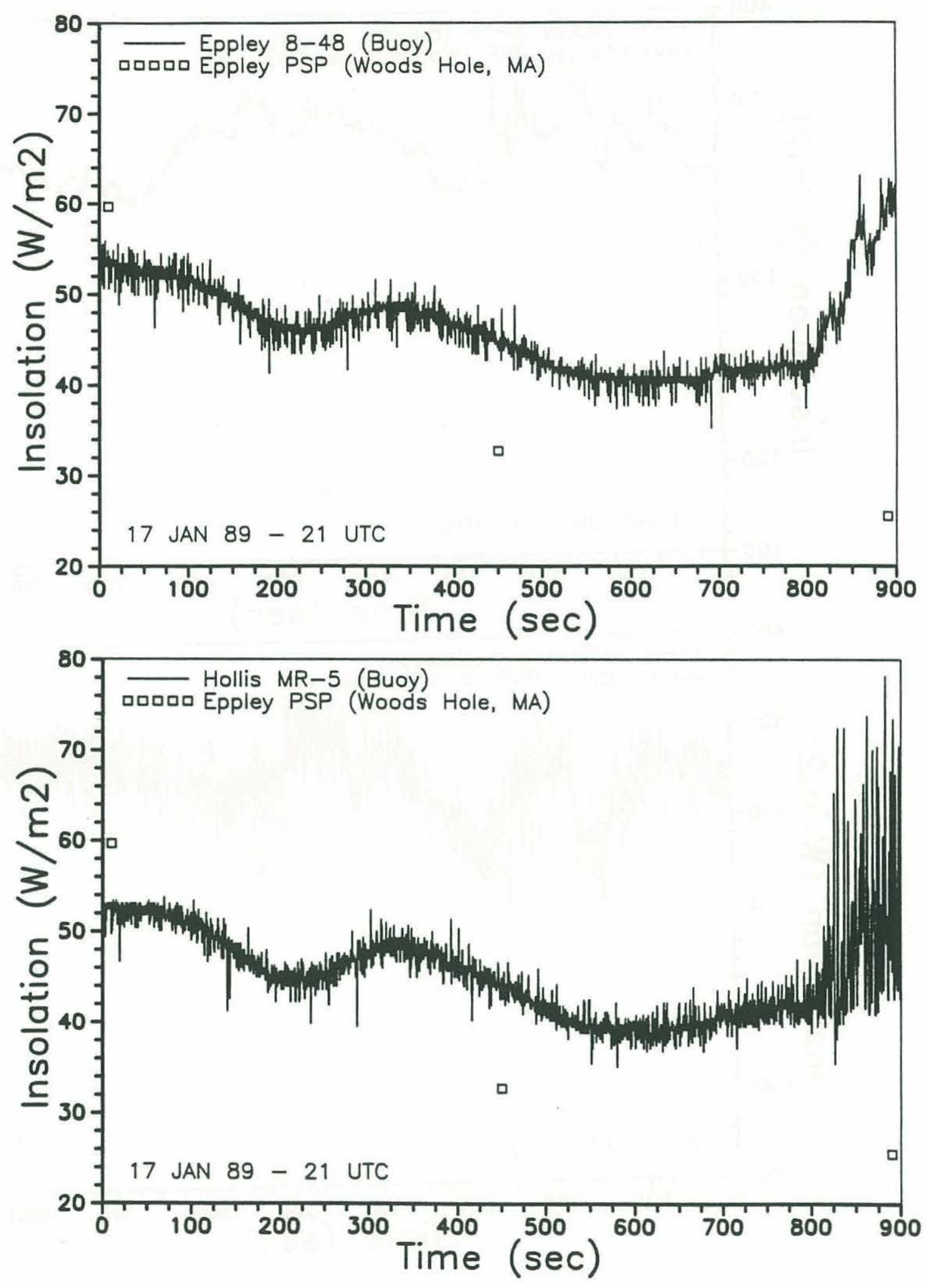

Figure 9: Insolation values recorded on test buoy on 17 January 1889 at 21 UTC. 

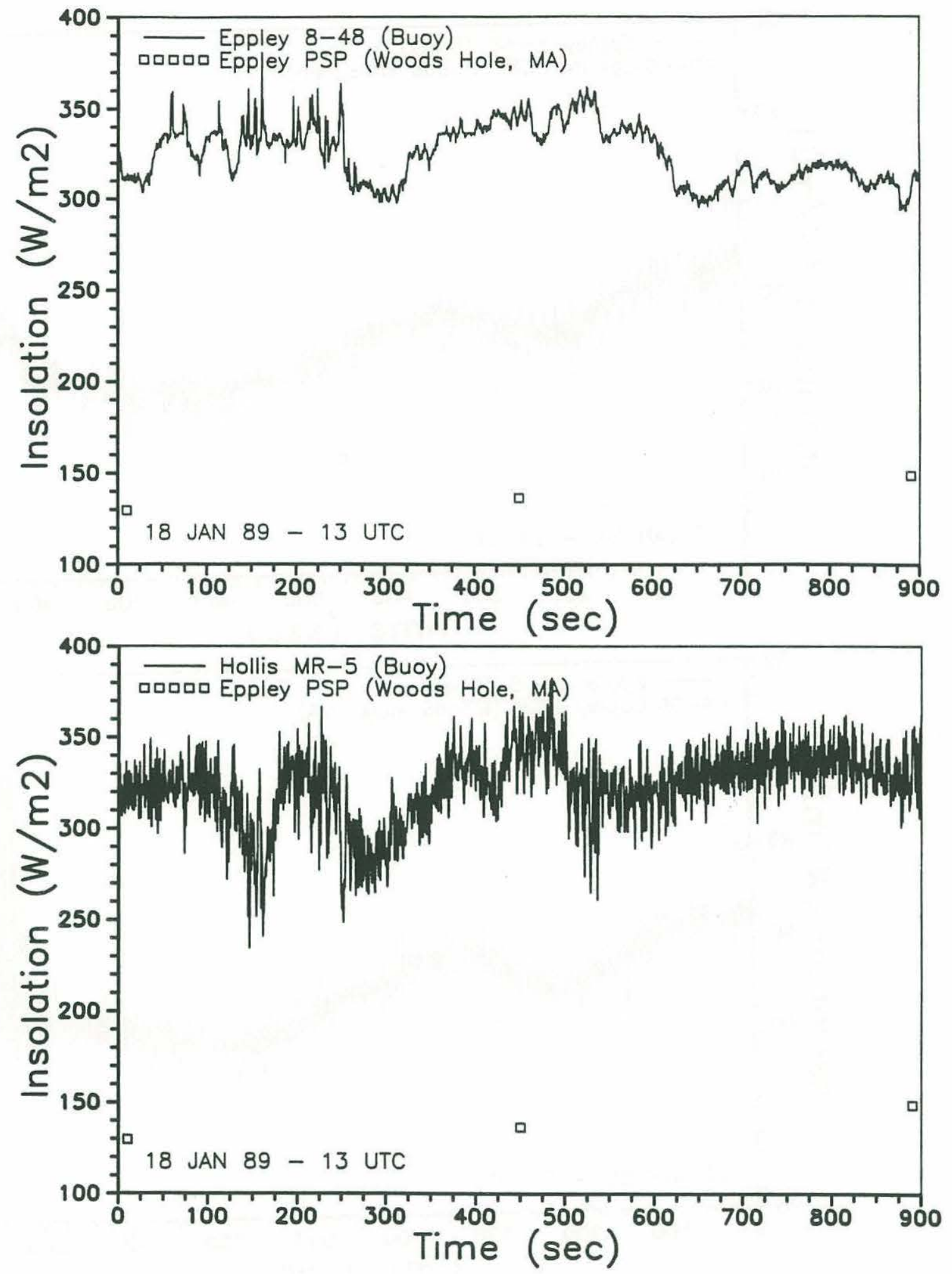

Figure 10: Insolation values recorded on test buoy on 18 January 1989 at 13 UTC. 

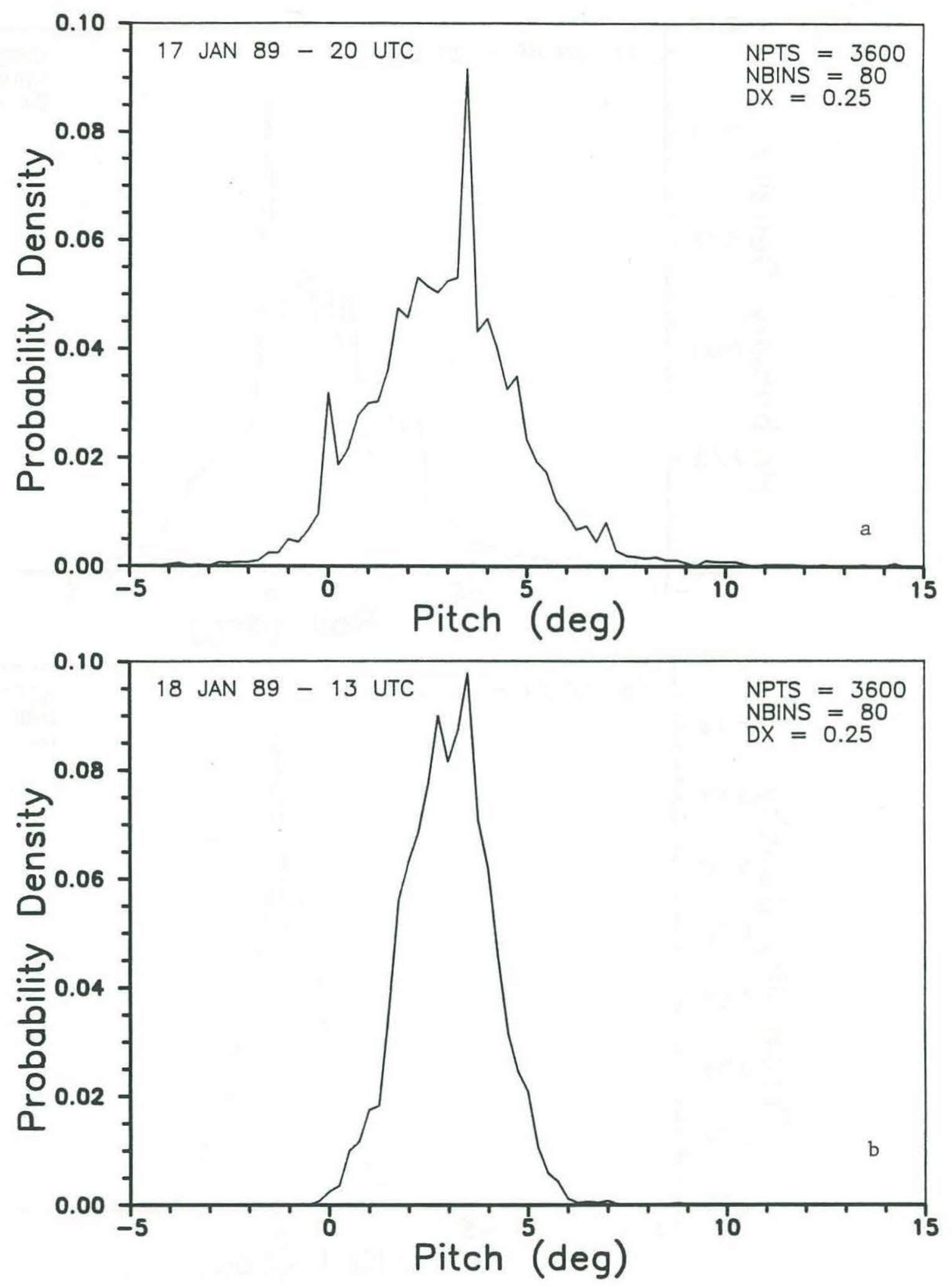

Figure 11: Probability density of buoy pitch for (a) 20 UTC on 17 January and (b) 13 UTC on 18 January. 

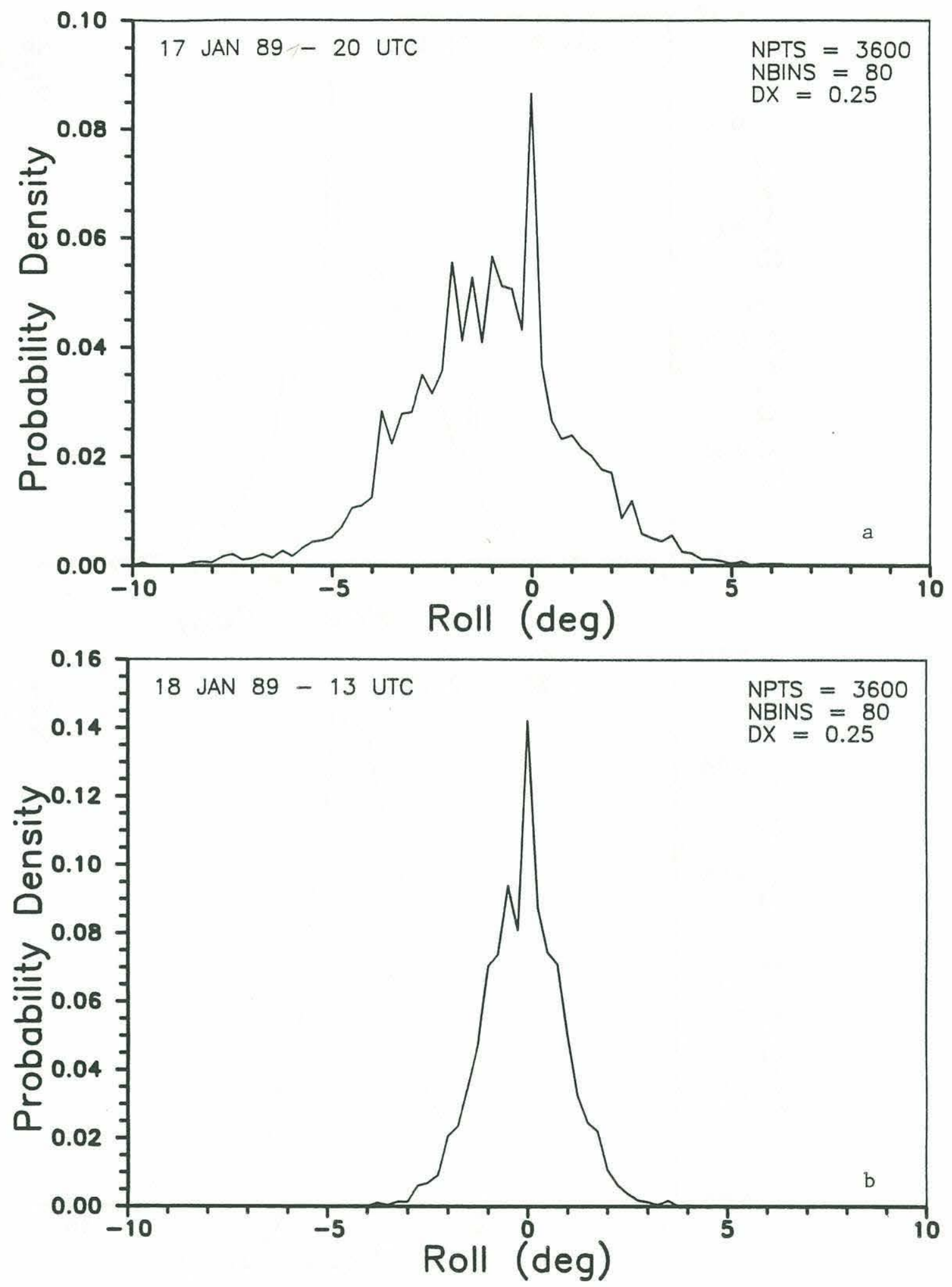

Figure 12: Probability density of buoy roll for (a) 20 UTC on 17 January and (b) 13 UTC on 18 January. 

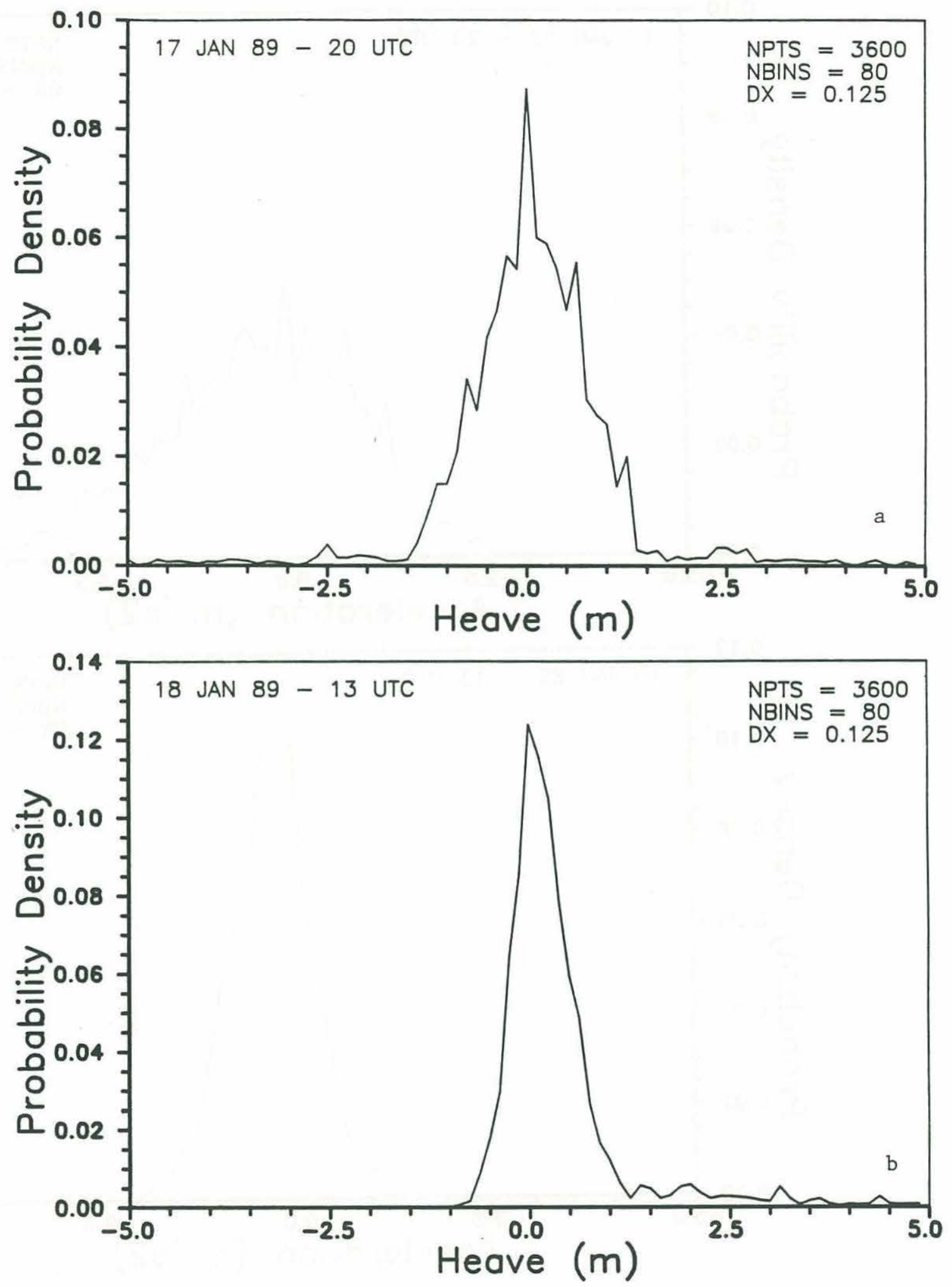

Figure 13: Probability density of buoy heave for (a) 20 UTC on 17 January and (b) 13 UTC on 18 January. 

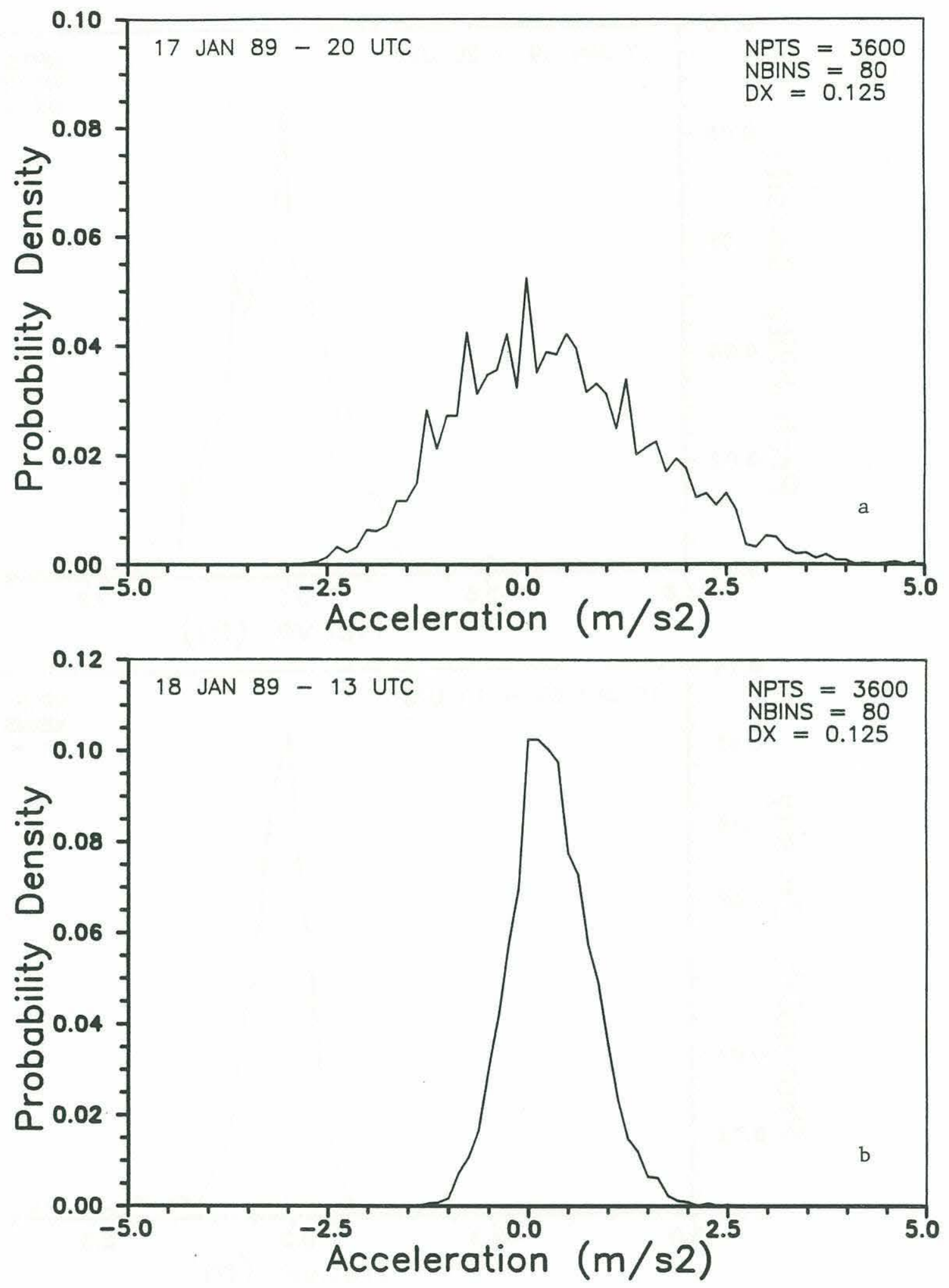

Figure 14: Probability density of buoy vertical acceleration for (a) 20 UTC on 17 January and (b) 13 UTC on 18 January. 


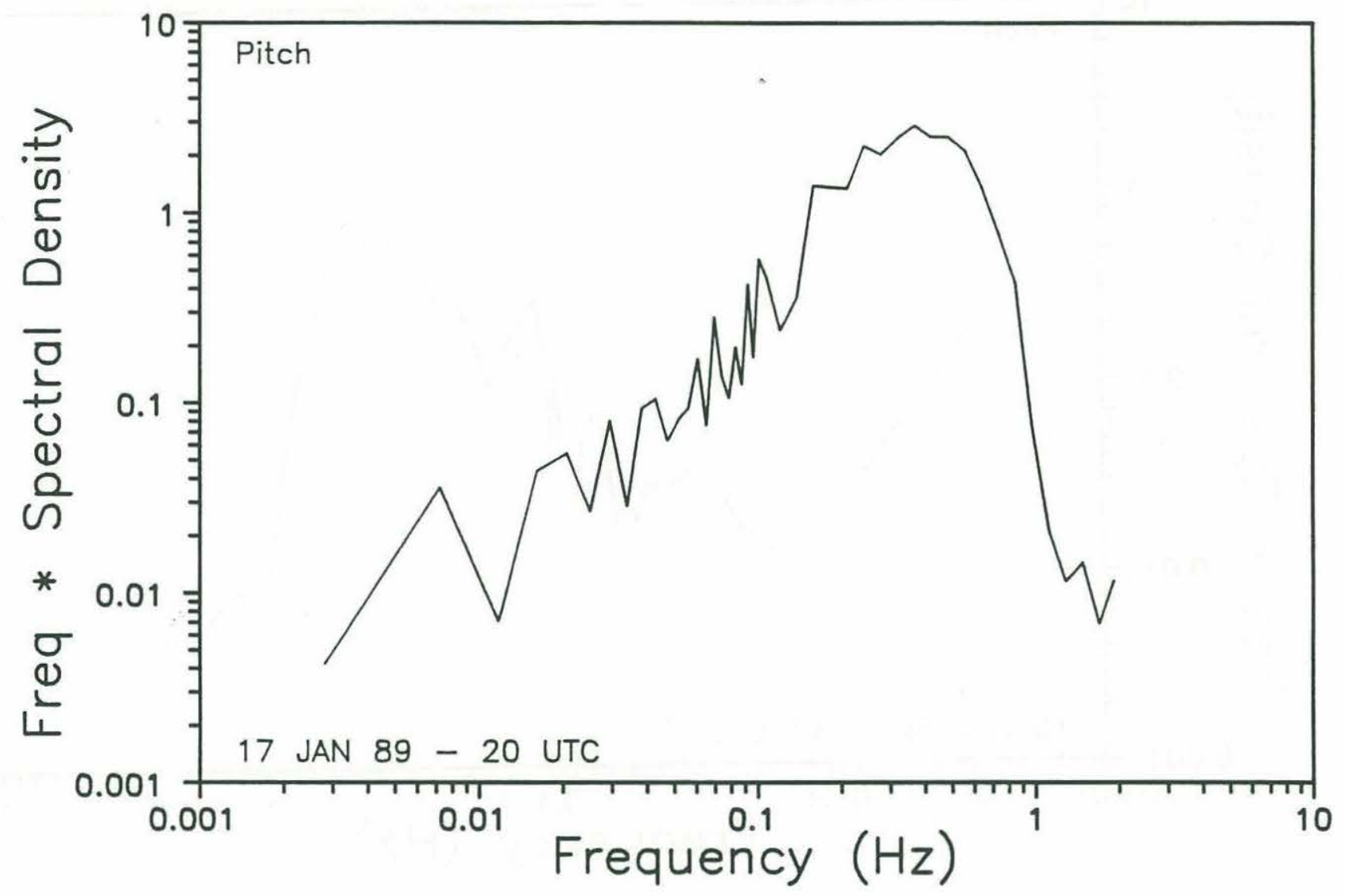

Figure 15: Spectra of buoy pitch for 20 UTC on 17 January. 


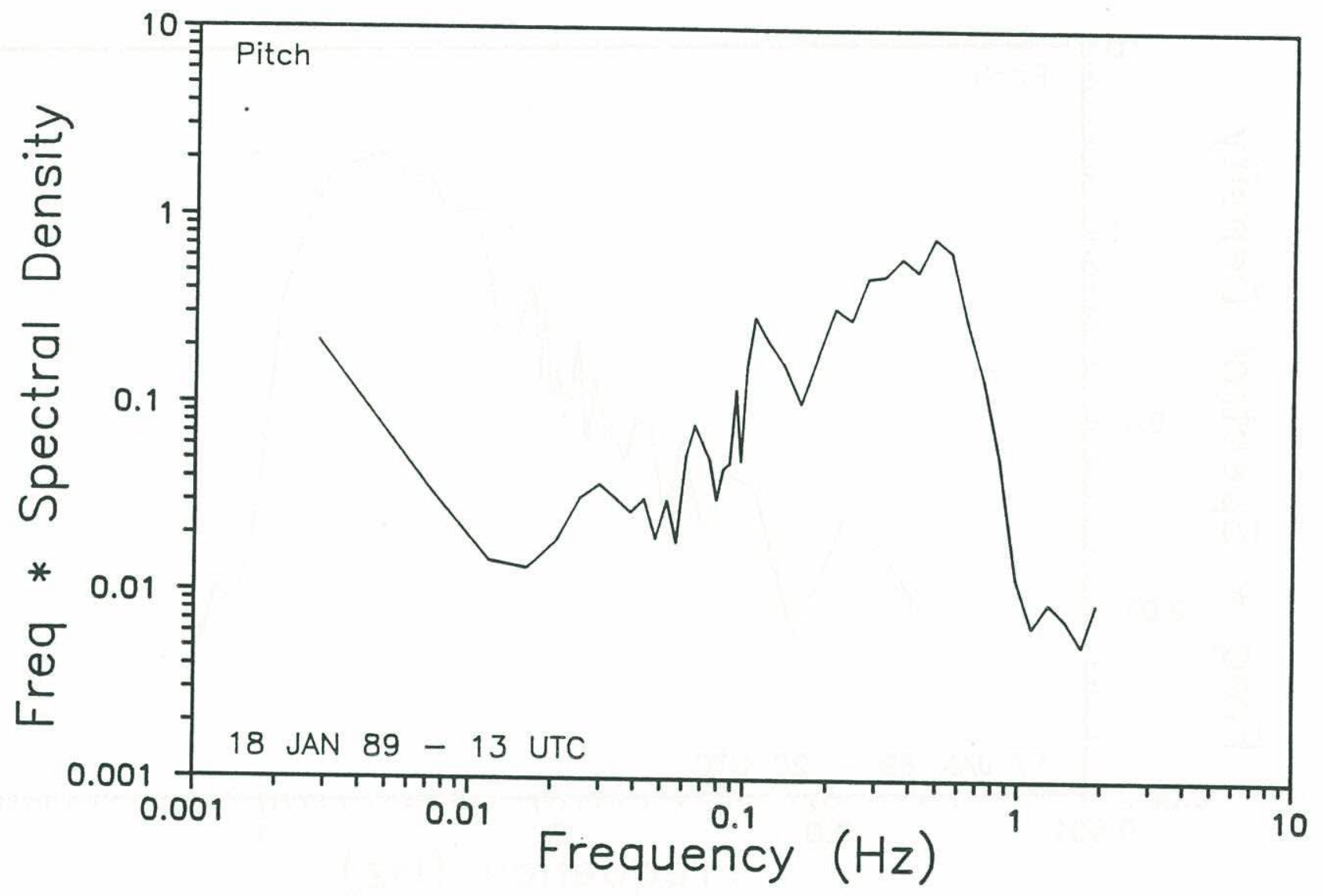

Figure 16: Spectra of buoy pitch for 13 UTC on 18 January. 


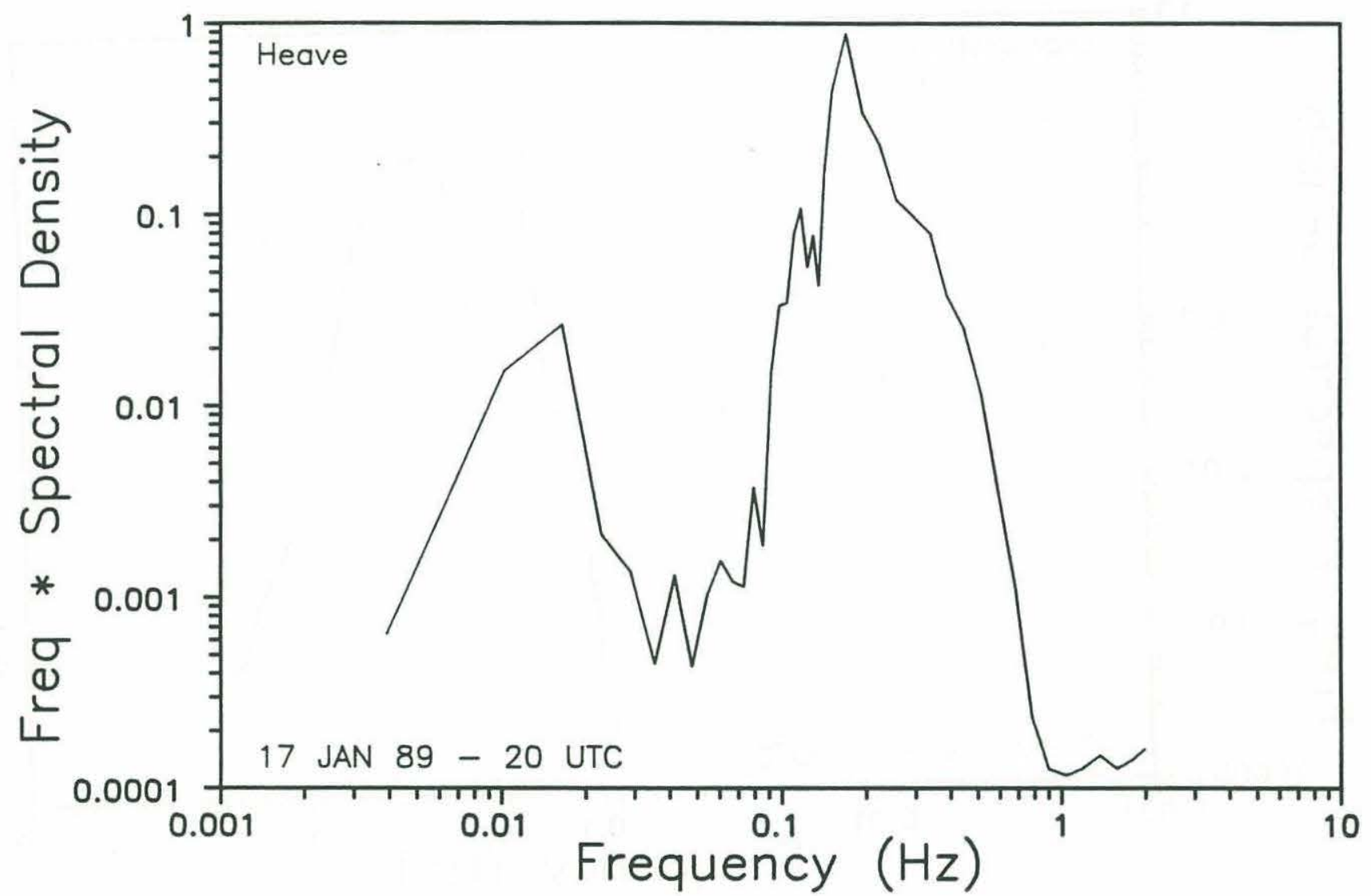

Figure 17: Spectra of buoy heave for 20 UTC on 17 January. 


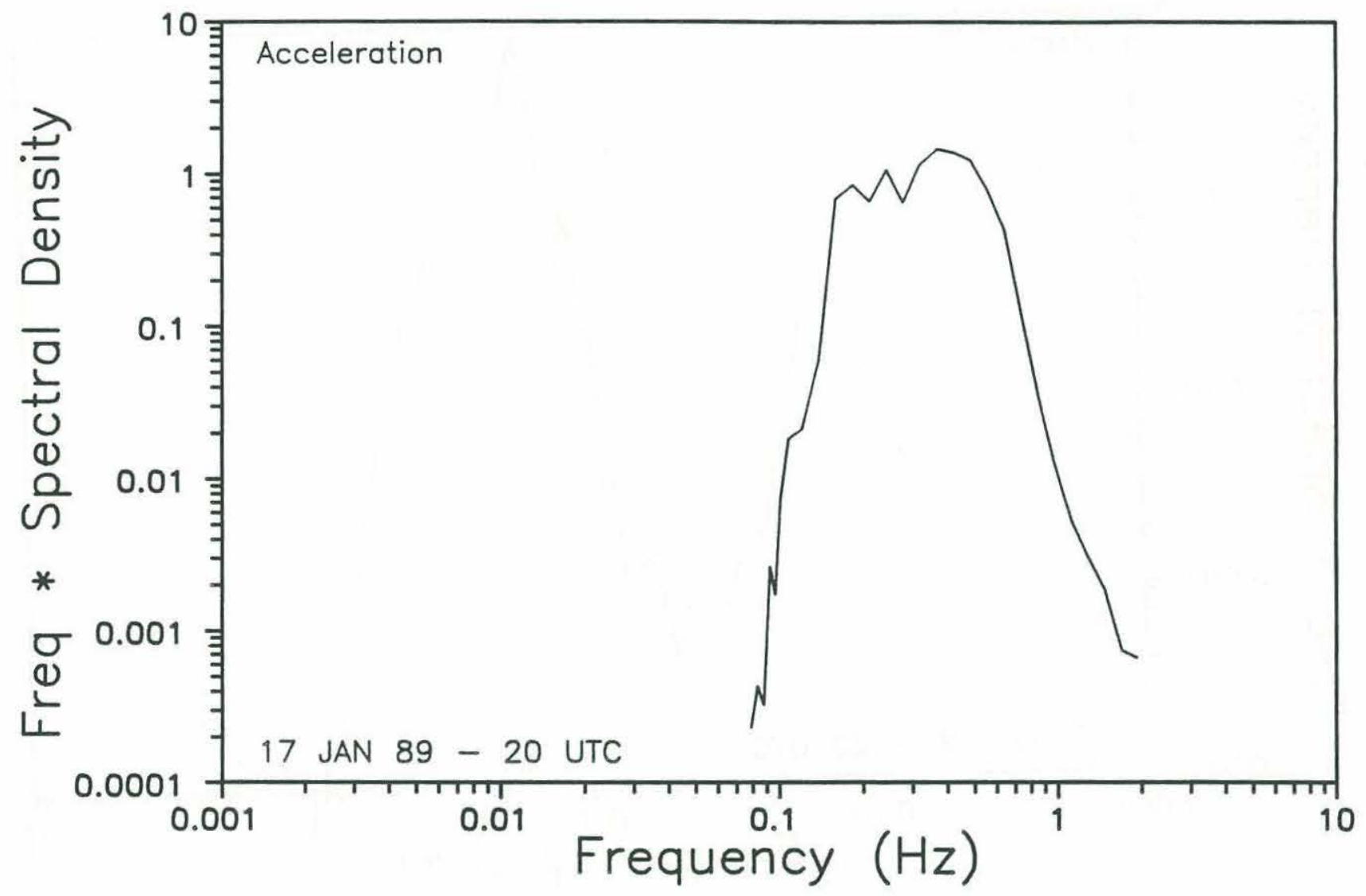

Figure 18: Spectra of buoy acceleration for 20 UTC on 17 January. 


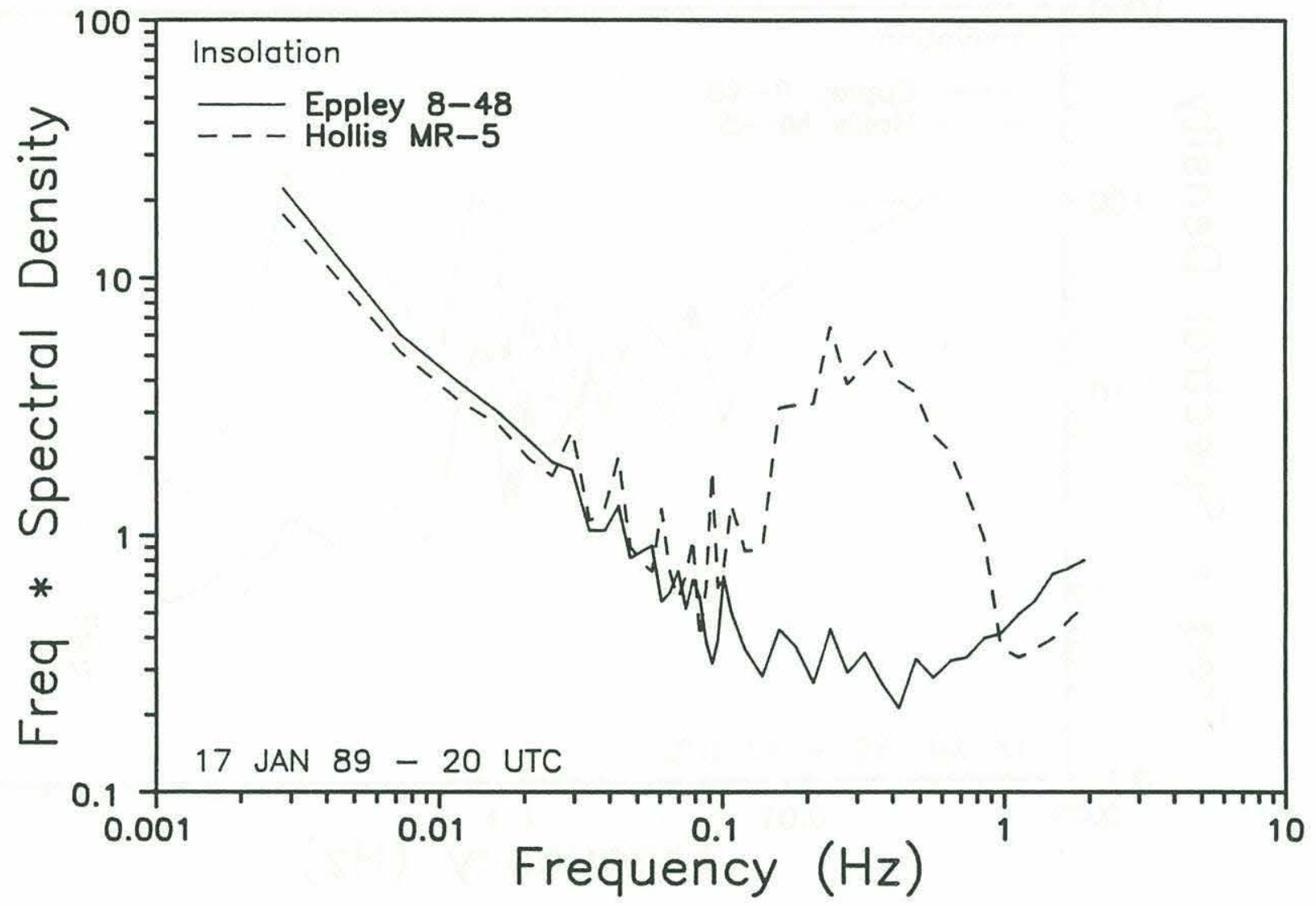

Figure 19: Spectra of insolation recorded by Eppley 8-48 (solid) and Hollis MR-5 (dashed) for 20 UTC on 17 January. 


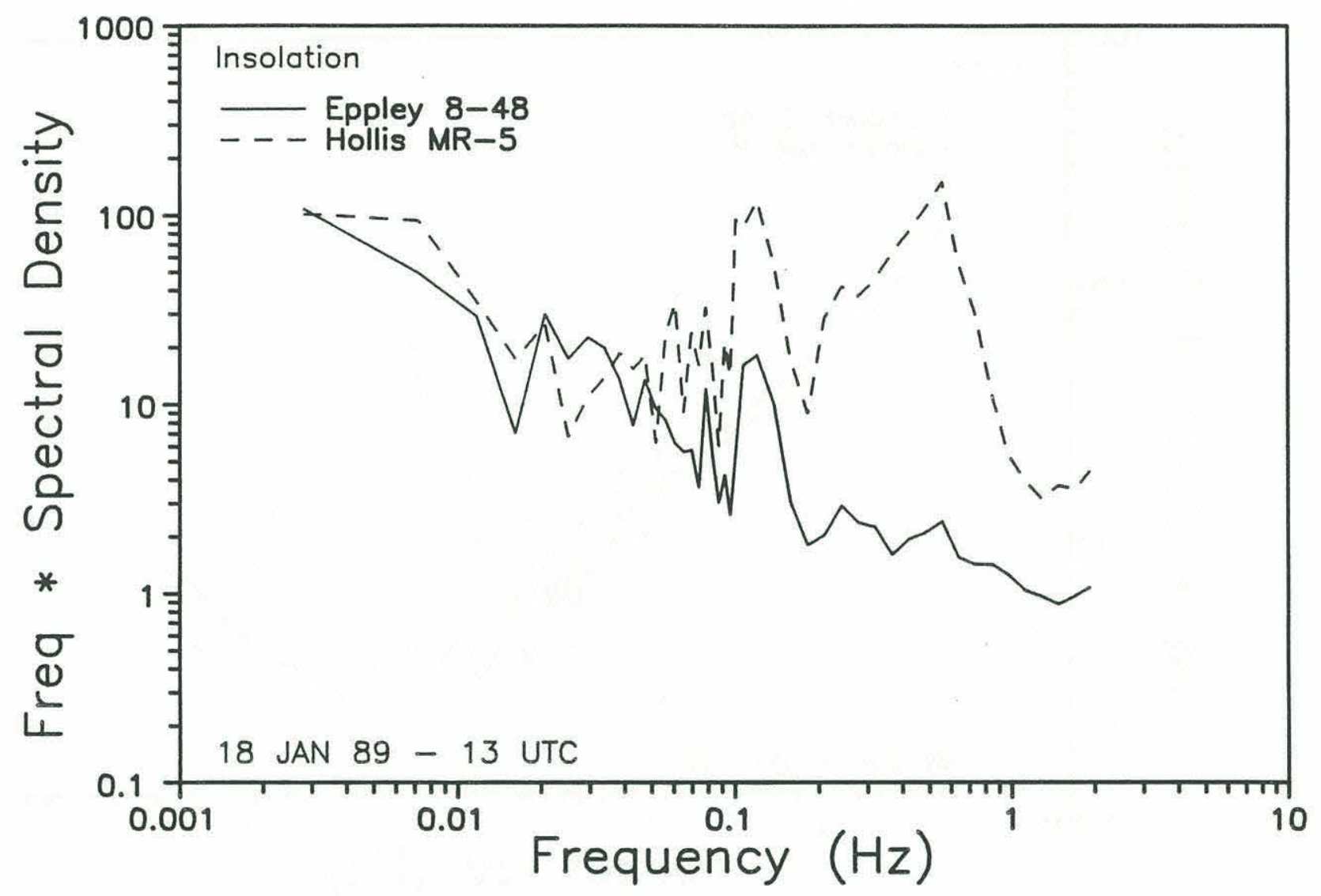

Figure 20: Spectra of insolation recorded by Eppley 8-48 (solid) and Hollis MR-5 (dashed) for 13 UTC on 18 January. 


\section{DOCUMENT LIBRARY}

July 5, 1989

\section{Distribution List for Technical Report Exchange}

Attn: Stella Sanchez-Wade

Documents Section

Scripps Institution of Oceanography

Library, Mail Code C-075C

La Jolla, CA 92093

Hancock Library of Biology \& Oceanography

Alan Hancock Laboratory

University of Southern California

University Park

Los Angeles, CA 90089-0371

Gifts \& Exchanges

Library

Bedford Institute of Oceanography

P.O. Box 1006

Dartmouth, NS, B2Y 4A2, CANADA

Office of the International

Ice Patrol

c/o Coast Guard R \& D Center

Avery Point

Groton, CT 06340

Library

Physical Oceanographic Laboratory

Nova University

8000 N. Ocean Drive

Dania, FL 33304

NOAA/EDIS Miami Library Center

4301 Rickenbacker Causeway

Miami, FL 33149

\section{Library}

Skidaway Institute of Oceanography

P.O. Box 13687

Savannah, GA 31416

Institute of Geophysics

University of Hawaii

Library Room 252

2525 Correa Road

Honolulu, HI 96822

Library

Chesapeake Bay Institute

4800 Atwell Road

Shady Side, MD 20876

MIT Libraries

Serial Journal Room 14E-210

Cambridge, MA 02139
Director, Ralph M. Parsons Laboratory

Room 48-311

MIT

Cambridge, MA 02139

Marine Resources Information Center

Building E38-320

MIT

Cambridge, MA 02139

Library

Lamont-Doherty Geological Observatory

Colombia University

Palisades, NY 10964

Library

Serials Department

Oregon State University

Corvallis, OR 97331

Pell Marine Science Library

University of Rhode Island

Narragansett Bay Campus

Narragansett, RI 02882

Working Collection

Texas A\&M University

Dept. of Oceanography

College Station, TX 77843

Library

Virginia Institute of Marine Science

Gloucester Point, VA 23062

Fisheries-Oceanography Library

151 Oceanography Teaching Bldg.

University of Washington

Seattle, WA 98195

Library

R.S.M.A.S.

University of Miami

4600 Rickenbacker Causeway

Miami, FL 33149

Maury Oceanographic Library

Naval Oceanographic Office

Bay St. Louis

NSTL, MS 39522-5001

Marine Sciences Collection

Mayaguez Campus Library

University of Puerto Rico

Mayagues, Puerto Rico 00708 


\begin{tabular}{|c|c|c|c|}
\hline $\begin{array}{l}\text { REPORT DOCUMENTATION } \\
\text { PAGE }\end{array}$ & $\begin{array}{l}\text { 1. REPORT NO. } \\
\text { WHOI-89-45 }\end{array}$ & 2. IMET TR-89-02 & 3. Recipient's Accession No. \\
\hline \multirow{2}{*}{\multicolumn{3}{|c|}{$\begin{array}{l}\text { 4. Title and Subtitle } \\
\text { Improved Meteorological Measurements from Buoys and Ships (IMET): } \\
\text { Preliminary Analysis of Solar Radiation and Motion Data from IMET Test Buoy. }\end{array}$}} & $\begin{array}{l}\text { 5. Report Date } \\
\text { October, } 1989\end{array}$ \\
\hline & & & 6. \\
\hline \multicolumn{3}{|c|}{$\begin{array}{l}\text { 7. Author(s) } \\
\text { Gennaro H. Crescenti and Robert A. Weller, David S. Hosom and Kenneth E. Prada }\end{array}$} & $\begin{array}{l}\text { 8. Performing Organization Rept. No. } \\
\text { WHOI- } 89-45\end{array}$ \\
\hline \multirow{2}{*}{\multicolumn{3}{|c|}{$\begin{array}{l}\text { 9. Performing Organization Name and Address } \\
\text { The Woods Hole Oceanographic Institution } \\
\text { Woods Hole, Massachusetts } 02543\end{array}$}} & 10. Project/Task/Work Unit No. \\
\hline & & & $\begin{array}{l}\text { 11. Contract(C) or Grant(G) No. } \\
\text { (C) } \\
\text { (G) OCE } 87-09614\end{array}$ \\
\hline \multicolumn{3}{|c|}{ 12. Sponsoring Organization Name and Address } & $\begin{array}{l}\text { 13. Type of Report \& Period Covered } \\
\text { Technical Report }\end{array}$ \\
\hline \multicolumn{3}{|c|}{ The National Science Foundation } & 14. \\
\hline
\end{tabular}

15. Supplementary Notes

This report should be cited as: Woods Hole Oceanog. Inst. Tech. Rept., WHOI-89-45, IMET TR-89-02

16. Abstract (Limit: 200 words)

Data are analyzed from a test buoy equipped with a motion sensor (Hippy) and two different pyranometers in order to understand and quantify motion induced errors in meteorological data. The Hippy measures pitch, roll, heave and acceleration of the buoy. Probability density functions and spectra of buoy motion and insolation are constructed and discussed.

17. Document Analysis a. Descriptors

1. solar radiation measurements

2. buoy motion

3. ship and buoy instrumentation

b. Identifiers/Open-Ended Terms

c. COSATI Field/Group

18. Availability Statement

Approved for publication; distribution unlimited.

\begin{tabular}{|c|c|}
\hline $\begin{array}{c}\text { 19. Security Class (This Report) } \\
\text { UNCLASSIFIED }\end{array}$ & $\begin{array}{c}\text { 21. No. of Pages } \\
38\end{array}$ \\
\hline 20. Security Class (This Page) & 22. Price \\
\hline
\end{tabular}

